University of Wollongong

Research Online

Australian Institute for Innovative Materials -

Papers

Australian Institute for Innovative Materials

$1-1-2017$

Gallium-Doped Li7La3Zr2012 Garnet-Type Electrolytes with High LithiumIon Conductivity

Jiang-Fang Wu

Huazhong University of Science and Technology

En-Yi Chen

Huazhong University of Science and Technology

Yao Yu

Huazhong University of Science and Technology

Lin Liu

Yue Wu

University of North Carolina, yw282@uowmail.edu.au

See next page for additional authors

Follow this and additional works at: https://ro.uow.edu.au/aiimpapers

Part of the Engineering Commons, and the Physical Sciences and Mathematics Commons

Research Online is the open access institutional repository for the University of Wollongong. For further information contact the UOW Library: research-pubs@uow.edu.au 


\title{
Gallium-Doped Li7La3Zr2012 Garnet-Type Electrolytes with High Lithium-Ion Conductivity
}

\author{
Abstract \\ Owing to their high conductivity, crystalline $\mathrm{Li} 7-3 x \mathrm{Ga}_{x} \mathrm{La}_{3} \mathrm{Zr}_{2} \mathrm{O}_{12}$ garnets are promising electrolytes for all- \\ solid-state lithium-ion batteries. Herein, the influence of $\mathrm{Ga}$ doping on the phase, lithium-ion distribution, \\ and conductivity of $\mathrm{Li}_{7}-3 x \mathrm{Ga}_{x} \mathrm{La}_{3} \mathrm{Zr}_{2} \mathrm{O}_{12}$ garnets is investigated, with the determined concentration and \\ mobility of lithium ions shedding light on the origin of the high conductivity of $\mathrm{Li}_{7}-3{ }_{x} \mathrm{Ga}_{x} \mathrm{La}_{3} \mathrm{Zr}_{2} \mathrm{O}_{12}$. When \\ the $\mathrm{Ga}$ concentration exceeds $0.20 \mathrm{Ga}$ per formula unit, the garnet-type material is found to assume a \\ cubic structure, but lower $\mathrm{Ga}$ concentrations result in the coexistence of cubic and tetragonal phases. \\ Most lithium within $\mathrm{Li}_{7}-3 x \mathrm{Ga}_{x} \mathrm{La}_{3} \mathrm{Zr}_{2} \mathrm{O}_{12}$ is found to reside at the octahedral $96 \mathrm{~h}$ site, away from the \\ central octahedral $48 \mathrm{~g}$ site, while the remaining lithium resides at the tetrahedral $24 d$ site. Such kind of \\ lithium distribution leads to high lithium-ion mobility, which is the origin of the high conductivity; the \\ highest lithium-ion conductivity of $1.46 \mathrm{mS} / \mathrm{cm}$ at $25^{\circ} \mathrm{C}$ is found to be achieved for $\mathrm{Li}_{7}-3 x \mathrm{Ga}_{x} \mathrm{La}_{3} \mathrm{Zr}_{2} \mathrm{O}_{12}$ at \\ $x=0.25$. Additionally, there are two lithium-ion migration pathways in the $\mathrm{Li} 7-3 x \mathrm{Ga}_{x} \mathrm{La}_{3} \mathrm{Zr}_{2} \mathrm{O}_{12}$ garnets: \\ $96 h-96 h$ and $24 d-96 h-24 d$, but the lithium ions transporting through the $96 h-96 h$ pathway determine the \\ overall conductivity. \\ Disciplines \\ Engineering | Physical Sciences and Mathematics

\section{Publication Details} \\ Wu, J., Chen, E., Yu, Y., Liu, L., Wu, Y., Pang, W., Peterson, V. \& Guo, X. (2017). Gallium-Doped Li7La3Zr2012 \\ Garnet-Type Electrolytes with High Lithium-Ion Conductivity. ACS Applied Materials and Interfaces, 9 (2), \\ 1542-1552.

\section{Authors} \\ Jiang-Fang Wu, En-Yi Chen, Yao Yu, Lin Liu, Yue Wu, Wei Kong Pang, Vanessa K. Peterson, and Xin Guo
}




\section{Gallium-doped $\mathrm{Li}_{7} \mathrm{La}_{3} \mathrm{Zr}_{2} \mathrm{O}_{12}$ garnet-type electrolytes with high lithium-ion conductivity}

Jian-Fang $\mathrm{Wu}^{1}$, En-Yi Chen ${ }^{1}$, Yao $\mathrm{Yu}^{1}$, Lin Liu ${ }^{1}$, Yue Wu ${ }^{1,2}$, Wei Kong Pang ${ }^{3,4}$, Vanessa K. Peterson ${ }^{3,4}$, Xin Guo ${ }^{1 *}$

1. School of Materials Science and Engineering, Huazhong University of Science and Technology, Wuhan 430074, P.R. China

2. Department of Physics and Astronomy, University of North Carolina, Chapel Hill, North Carolina 27599-3255, USA

3. Australian Centre for Neutron Scattering, Australian Nuclear Science and Technology Organisation, Locked Bag 2001, Kirrawee DC, New South Wales 2232, Australia

4. Institute for Superconducting \& Electronic Materials, Faculty of Engineering, University of Wollongong, NSW 2522, Australia

* Author to whom correspondence should be addressed.

Tel: +86-27-87559804; Fax: +86-27-87559804; E-mail: xguo@hust.edu.cn 


\section{Abstract}

Owing to their high conductivity, crystalline $\mathrm{Li}_{7-3 x} \mathrm{Ga}_{x} \mathrm{La}_{3} \mathrm{Zr}_{2} \mathrm{O}_{12}$ garnets are promising electrolytes for all-solid-state lithium-ion batteries. Herein, the influence of Ga doping on the phase, lithium-ion distribution, and conductivity of $\mathrm{Li}_{7-3 x} \mathrm{Ga}_{x} \mathrm{La}_{3} \mathrm{Zr}_{2} \mathrm{O}_{12}$ garnets is investigated, with the determined concentration and mobility of lithium ions shedding light on the origin of the high conductivity of $\mathrm{Li}_{7-3 x} \mathrm{Ga}_{x} \mathrm{La}_{3} \mathrm{Zr}_{2} \mathrm{O}_{12}$. When the Ga concentration exceeds $0.20 \mathrm{Ga}$ per formula unit, the garnet-type material is found to assume a cubic structure, but lower Ga concentrations result in the coexistence of cubic and tetragonal phases. Most lithium within $\mathrm{Li}_{7-3 x} \mathrm{Ga}_{x} \mathrm{La}_{3} \mathrm{Zr}_{2} \mathrm{O}_{12}$ is found to reside at the octahedral $96 h$ site, away from the central octahedral $48 g$ site, while the remaining lithium resides at the tetrahedral $24 d$ site. Such kind of lithium distribution leads to high lithium-ion mobility, which is the origin of the high conductivity; the highest lithium-ion conductivity of $1.46 \mathrm{mS} / \mathrm{cm}$ at $25{ }^{\circ} \mathrm{C}$ is found to be achieved for $\mathrm{Li}_{7-3 x} \mathrm{Ga}_{x} \mathrm{La}_{3} \mathrm{Zr}_{2} \mathrm{O}_{12}$ at $x=0.25$. Additionally, there are two lithium-ion migration pathways in the $\mathrm{Li}_{7-3 x} \mathrm{Ga}_{x} \mathrm{La}_{3} \mathrm{Zr}_{2} \mathrm{O}_{12}$ garnets: $96 h-96 h$ and $24 d-96 h-24 d$, but the lithium ions transporting through the $96 h-96 h$ pathway determine the overall conductivity.

Keywords: $\mathrm{Li}_{7-3 x} \mathrm{Ga}_{x} \mathrm{La}_{3} \mathrm{Zr}_{2} \mathrm{O}_{12}$ garnet, lithium ion, lithium vacancy, ionic conductivity, mobility 


\section{Introduction}

Lithium ion batteries are one of the most promising energy storing devices, offering high volumetric and gravimetric energy density compared with other battery technologies ${ }^{1}$. However, the flammability of organic liquid electrolytes results in notorious safety issues that hamper their full utilization in electric vehicles and stationary energy storage systems ${ }^{1,2}$. Solid electrolytes are advantageous to conventional electrolytes in solving such safety issues. Additionally, their excellent stability potentially enables metallic $\mathrm{Li}$ to be used as a negative electrode, which, in combination with a high-voltage positive electrode, could provide high energy density and long cycle life. Consequently, all-solid-state lithium-ion batteries based on solid electrolytes are attracting increasing attention in battery research ${ }^{3-6}$. In some cases, in which power sources are to be operated under extreme environmental conditions, such as at high temperature and pressure in space, in defense applications and oil and gas exploration, all-solid-state lithium-ion batteries are clearly the best choice ${ }^{7}$.

Amongst the oxide solid electrolytes, $\mathrm{Li}_{7} \mathrm{La}_{3} \mathrm{Zr}_{2} \mathrm{O}_{12}$ (LLZO) garnets are regarded as ideal candidates for lithium ion batteries ${ }^{5,8-10}$. LLZO was first synthesized and characterized by Murugan et al. ${ }^{11}$, although it was only recently that Geiger et al. showed that LLZO is crystallized with both cubic and tetragonal symmetry, with the cubic phase exhibiting a lithium-ion conductivity two orders of magnitude higher than that for the tetragonal phase ${ }^{12} \cdot \mathrm{Li}_{7} \mathrm{La}_{3} \mathrm{Zr}_{2} \mathrm{O}_{12}$ is formed by a three-dimensional $\mathrm{La}_{3} \mathrm{Zr}_{2} \mathrm{O}_{12}$-type framework structure consisting of 8-coordinate $\mathrm{La}^{3+}$ and 6-cordinate $\mathrm{Zr}^{4+}$, where two tetrahedral sites are bridged by a single octahedron via face-sharing, 
constructing a migration pathway for lithium ions. The lithium ion distribution is the key factor in determining the modification of LLZO ${ }^{13}$. Tetragonal LLZO contains a completely ordered distribution of lithium ions and crystallizes in the space group $I 4_{1} / a c d$. Cubic LLZO crystallizes in the space-group $I a \overline{3} d$, and exhibits a disordered lithium ion distribution and vacancies caused by lithium deficiency. Cation doping increases the number of vacancies and results in a disordered Li sublattice, where all Li sites are partially occupied in the LLZO structure. $\mathrm{Ta}^{5+14}, \mathrm{Nb}^{5+15}, \mathrm{Te}^{6+16}$, and $\mathrm{W}^{6+}$ ${ }^{17}$ that substitute on the $\mathrm{Zr}^{4+}$ site, as well as $\mathrm{Al}^{3+11}$ and $\mathrm{Ga}^{3+18-26}$ that substitute in the Li sublattice, have been employed to stabilize the cubic phase.

The lithium-ion conductivity $(\sigma)$ of LLZO can be expressed by the following equation:

$\sigma=e \cdot n_{\mathrm{c}} \cdot \mu$

in which $e$ is the elementary charge, $n_{c}$ the concentration of mobile Li ions, and $\mu$ the Li mobility. Therefore, the lithium-ion conductivity of LLZO is determined by the concentration and mobility of mobile lithium ions, both of which can be tuned by doping.

In the $\mathrm{Li}_{7-x} \mathrm{La}_{3} \mathrm{Zr}_{2-x} \mathrm{Ta}_{x} \mathrm{O}_{12}$ system, a maximum value of lithium-ion conductivity was theoretically demonstrated to be $\sim 6.4 \mathrm{Li}$ per formula unit ${ }^{13,27}$. Not all lithium ions can contribute to conduction simultaneously, because only 2.6 vacancies per formula are available in $\mathrm{Li}_{6.4} \mathrm{La}_{3} \mathrm{Zr}_{1.4} \mathrm{Ta}_{0.6} \mathrm{O}_{12}$. Ahmad estimated that the concentration of charge carriers in LLZO is $\sim 12.3 \%{ }^{28}$, which is close to that found for W-doped LLZO $^{29}$. The majority of lithium ions are trapped and the concentration of vacancies 
is higher than that of the mobile lithium ions, it is therefore possible to improve the lithium-ion conductivity of LLZO by activating lithium ions to participate in conduction. Additionally, enlarging the size of the lithium-ion migration pathway can increase the mobility of lithium ions ${ }^{30}$. This may also be achieved by strategic doping in cubic LLZO, such as by doping $\mathrm{Sr}^{2+}$ onto $\mathrm{La}^{3+}$ sites.

Moreover, there are coulombic interactions between the ions in the migration pathway due to their small separation distance ${ }^{31-33}$, and it is conceivable that the coulombic repulsion between dopants, such as $\mathrm{Al}^{3+}, \mathrm{Zn}^{2+}$ and $\mathrm{Ga}^{3+}$, and $\mathrm{Li}^{+}$is stronger than that between lithium ions; such coulombic repulsion can activate lithium ions. Thus, lithium ions can be activated by proper doping, which affects the concentration and mobility of charge carriers.

Among all dopants, $\mathrm{Ga}$ is the most effective in enhancing the lithium-ion conductivity ${ }^{23,34} \cdot \mathrm{Ga}_{2} \mathrm{O}_{3}$ is introduced into LLZO according to $\mathrm{Ga}_{2} \mathrm{O}_{3}+6 \mathrm{Li}_{L i}^{\times} \rightarrow 2 \mathrm{Ga} \ddot{L i}+4 V_{L i}^{\prime}+3 \mathrm{Li}_{2} \mathrm{O}$.

Although several researchers reported improved lithium-ion conductivity of LLZO by Ga-doping ${ }^{18-21,24}$, the reported lithium-ion conductivity was only $\sim 10^{-4} \mathrm{~S} / \mathrm{cm}$. More recently Bernuy-Lopez et al. reported a lithium-ion conductivity of $1.3 \mathrm{mS} / \mathrm{cm}$ for $\mathrm{Li}_{6.4} \mathrm{Ga}_{0.2} \mathrm{La}_{3} \mathrm{Zr}_{2} \mathrm{O}_{12}$ at $24{ }^{\circ} \mathrm{C}$, and showed, using nuclear magnetic resonance measurements, that the $\mathrm{Ga}^{3+}$ was located on tetrahedral sites ${ }^{23}$. Jalem et al. tried to explain the high conductivity of Ga-doped LLZO through understanding the influence of $\mathrm{Ga}^{3+}$ on the Li site connectivity using molecular dynamics simulations, with their results showing that $>90 \%$ connectivity was retained up to $x=0.30$ in 
$\mathrm{Li}_{7-3 x} \mathrm{Ga}_{x} \mathrm{La}_{3} \mathrm{Zr}_{2} \mathrm{O}_{12}{ }^{22}$. Even more recently, Rettenwander et al. reported a lithium-ion conductivity of $1.32 \mathrm{mS} / \mathrm{cm}$ for $\mathrm{Li}_{6.4} \mathrm{Ga}_{0.2} \mathrm{La}_{3} \mathrm{Zr}_{2} \mathrm{O}_{12}$ at $20{ }^{\circ} \mathrm{C}$, with a detailed study of the crystalline structure explaining the high lithium-ion conductivity ${ }^{34}$. In this work, the lithium-ion conductivity of LLZO at room temperature is improved to $1.46 \mathrm{mS} / \mathrm{cm}$ through Ga-doping, and the origin of high lithium-ion conductivity of $\mathrm{Li}_{7-3 x} \mathrm{Ga}_{x} \mathrm{La}_{3} \mathrm{Zr}_{2} \mathrm{O}_{12}$ electrolytes is expounded.

\section{Experimental}

\subsection{Sample preparation}

$\mathrm{Li}_{7-3 x} \mathrm{Ga}_{x} \mathrm{La}_{3} \mathrm{Zr}_{2} \mathrm{O}_{12}(x=0.10,0.15,0.20,0.25,0.30,0.35$, and 0.40$)$ electrolytes were prepared via a solid-state reaction from $\mathrm{Li}_{2} \mathrm{CO}_{3}, \mathrm{La}_{2} \mathrm{O}_{3}, \mathrm{ZrO}_{2}$, and $\mathrm{Ga}_{2} \mathrm{O}_{3} .10$ mol.\% excess of $\mathrm{Li}_{2} \mathrm{CO}_{3}$ was used to compensate the lithium loss during high temperature calcination. The powders were ball-milled for $15 \mathrm{~h}$, heated in air at $900{ }^{\circ} \mathrm{C}$ for $6 \mathrm{~h}$, followed by ball-milling for another $15 \mathrm{~h}$. The powders were then cold isostatically pressed into pellets at $250 \mathrm{MPa}$ and sintered at $1100{ }^{\circ} \mathrm{C}$ for $24 \mathrm{~h}$ in air. In order to avoid $\mathrm{Al}^{3+}$ contamination, a pellet of the same composition was put between the crucible and the sample during sintering. The samples were also covered with respective mother powders to prevent Li loss during sintering.

\subsection{Composition and structure characterization}

The chemical compositions of the samples were determined by inductively coupled plasma optical emission spectroscopy (ICP-OES) with an Optima 4300DV (America PerkinElmer Corporation). The relative densities of the samples were measured by the Archimedes method using water. Preliminary characterization of the crystalline 
phases was performed using X-ray diffraction (XRD) with a XRD-7000S (Japan Shimadzu Corporation). Raman spectra were recorded in the range of 50 to $1200 \mathrm{~cm}^{-1}$ at room temperature (LabRAM HR800, France Horiba JobinYvon Corporation). Neutron powder diffraction (NPD) data were collected using ECHIDNA, the high-resolution neutron powder diffractometer at the Australian Nuclear Science and Technology Organisation (ANSTO) ${ }^{35}$. The neutron beam wavelength was determined to be $0.162172(5) \mathrm{nm}$ using the $\mathrm{La}^{11} \mathrm{~B}_{6}$ NIST standard reference material (SRM 660b). GSAS-II was used to analyze the NPD data ${ }^{36} \cdot{ }^{6} \mathrm{Li}$ magic angle spinning nuclear magnetic resonance (MAS NMR) spectra were used to probe the local chemical environment of Li atoms and analyze the lithium-ion dynamics. The ${ }^{6} \mathrm{Li}$ MAS NMR spectra were gathered at a Larmor frequency of $58.9 \mathrm{MHz}$ on a Bruker Avance III 400 NMR spectrometer with a sample spinning speed of $20 \mathrm{kHz}$. The chemical shifts of ${ }^{6} \mathrm{Li}$ were calibrated by using a $1 \mathrm{M} \mathrm{LiCl}$ solution. ${ }^{6} \mathrm{Li}$ MAS NMR spectra were collected using a $\pi / 2$ pulse with a length of $7.5 \mu s$ and a recycle delay of $100 \mathrm{~s}$. The spin lattice relaxation was characterized by the saturation recovery method.

\subsection{Conductivity measurements}

AC impedance measurements were undertaken to measure conductivity in the temperature range -60 to $60{ }^{\circ} \mathrm{C}$ using a Solartron 1260 impedance and gain-phase analyzer in the frequency range of 1 to $5 \times 10^{6} \mathrm{~Hz}$ and at an amplitude of $50 \mathrm{mV}$. The sample is $\sim 12 \mathrm{~mm}$ in diameter and 2 to $3 \mathrm{~mm}$ in thickness. Li-ion blocking $\mathrm{Ag}$ electrodes on the large surfaces were used. Before each measurement, samples were annealed for $1 \mathrm{~h}$ at the desired temperature to ensure equilibrium. Cells with only Li 
electrodes were also prepared; two pieces of metallic Li were pasted on the large surfaces of the sample and heated at $120{ }^{\circ} \mathrm{C}$ for $3 \mathrm{~h}$ in a glovebox filled with Ar. The $\mathrm{Li} / \mathrm{LLZO} / \mathrm{Li}$ cell was sealed in the battery testing equipment for the $\mathrm{AC}$ impedance measurement at $30{ }^{\circ} \mathrm{C}$. By applying a DC voltage of $0.1 \mathrm{~V}$ to the $\mathrm{Ag} / \mathrm{LLZO} / \mathrm{Ag}$ cell, we also determined the electronic conductivity by means of the DC polarization method, and the current was recorded for $1000 s$ during the polarization.

\section{Results and discussion}

\subsection{Composition and structure}

The elemental composition of the $\mathrm{Li}_{7-3 x} \mathrm{Ga}_{x} \mathrm{La}_{3} \mathrm{Zr}_{2} \mathrm{O}_{12}$ samples obtained by ICP-OES (Table 1) are close to the nominal composition, with the exception of a slightly higher lithium content, likely as a result of an excess of $\mathrm{Li}$ in the starting materials. No aluminum contamination was found.

The relative densities of the samples obtained by the Archimedes method reveal relative densities below $90 \%$ for samples with $x=0.10$ and 0.15 and above $93 \%$ for well-sintered samples with $x \geq 0.20$.

XRD data of the $\mathrm{Li}_{7-3 x} \mathrm{Ga}_{x} \mathrm{La}_{3} \mathrm{Zr}_{2} \mathrm{O}_{12}$ samples are shown in Fig. 1(a), where all diffraction peaks can be assigned to a cubic garnet structure, although peaks from the $\mathrm{Li}_{6.70} \mathrm{Ga}_{0.10} \mathrm{La}_{3} \mathrm{Zr}_{2} \mathrm{O}_{12}$ and $\mathrm{Li}_{6.55} \mathrm{Ga}_{0.15} \mathrm{La}_{3} \mathrm{Zr}_{2} \mathrm{O}_{12}$ samples are broadened compared to those of the samples with $x \geq 0.20$, which could be attributed to the presence of the tetragonal garnet.

The Raman spectra of tetragonal and cubic garnets are readily distinguishable ${ }^{37,38}$. The Raman spectra of the samples are shown in Fig. 1(b). The typical Raman spectra 
of the LLZO garnets can be divided into three regions, a low-frequency region below $300 \mathrm{~cm}^{-1}$, an intermediate-frequency region between 300 and $550 \mathrm{~cm}^{-1}$, and a high-frequency region above $550 \mathrm{~cm}^{-1}$. The high-frequency region corresponds to the vibrational stretching modes of the $\mathrm{ZrO}_{6}$ octahedra, while the intermediate region has features mainly arising from vibrational bending modes of the octahedra, and the low-frequency region contains features corresponding to the translational modes of mobile ions. Features in the range of 100 to $300 \mathrm{~cm}^{-1}$ reveal the existence of the tetragonal garnet in the $\mathrm{Li}_{6.70} \mathrm{Ga}_{0.10} \mathrm{La}_{3} \mathrm{Zr}_{2} \mathrm{O}_{12}$ and $\mathrm{Li}_{6.55} \mathrm{Ga}_{0.15} \mathrm{La}_{3} \mathrm{Zr}_{2} \mathrm{O}_{12}$ samples, where sharp and split peaks arising from the reduction of symmetry from cubic to tetragonal exist ${ }^{37,38}$. Therefore, samples with $x=0.10$ and 0.15 contain both tetragonal and cubic phases, and increasing Ga content to $x \geq 0.20$ results in the pure cubic garnet.

\subsection{Lithium ion conductivity}

The conductivity of the $\mathrm{Li}_{7-3 x} \mathrm{Ga}_{\mathrm{x}} \mathrm{La}_{3} \mathrm{Zr}_{2} \mathrm{O}_{12}$ samples was measured by the $\mathrm{AC}$ impedance technique. Fig. 2 exhibits the impedance spectra and the fitting results for the $\mathrm{Li}_{6.25} \mathrm{Ga}_{0.25} \mathrm{La}_{3} \mathrm{Zr}_{2} \mathrm{O}_{12}$ sample under different conditions. When the testing temperature is $-60{ }^{\circ} \mathrm{C}$, a semi-circle and a dispersive line is seen in the spectrum, as shown in Fig. 2(a). With increasing temperature, the semi-circle reduces in size and vanishes at $0{ }^{\circ} \mathrm{C}$. In the range of 10 to $60{ }^{\circ} \mathrm{C}$, only a dispersive line is obtained, as shown in Fig. 2(b). The impedance spectra of the other samples are similar.

The intercept of the high frequency semi-circle of the impedance spectrum on the real axis represents the resistance of the sample, and the dispersive line represents the 
lithium-ion transfer resistance of the $\mathrm{Ag}$ electrodes. The capacitances for the semicircles at low temperatures are on the level of $10^{-11} \mathrm{~F}$, indicating a bulk property characteristic of LLZO electrolytes. Fig. 2(c) shows that when using Li electrodes the intercept of the high frequency semi-circle is almost identical to that obtained using Ag electrodes; therefore, the intercept of the high frequency semi-circle represents the sample resistance, while the intercept of the semi-circle at lower frequencies stands for the interfacial resistance between the sample and the Li electrodes.

Since it is impossible to distinguish the bulk and grain boundary resistances from the spectra, total conductivity is calculated here. The total conductivities of the samples at $25^{\circ} \mathrm{C}$ are given in Table 1 . When $x=0.10$ and 0.15 , the samples show low lithium-ion conductivities of 0.025 and $0.085 \mathrm{mS} / \mathrm{cm}$, respectively, at $25{ }^{\circ} \mathrm{C}$, due to the presence of the tetragonal garnet. With increasing Ga content, the total conductivity increases and then decreases, reaching a maximum at $x=0.25$. The total conductivity of $\mathrm{Li}_{6.25} \mathrm{Ga}_{0.25} \mathrm{La}_{3} \mathrm{Zr}_{2} \mathrm{O}_{12}$ at $25{ }^{\circ} \mathrm{C}$ is $1.46 \mathrm{mS} / \mathrm{cm}$. For comparison, the electrical properties of the LLZO electrolytes are summarized in Table 2. Generally, only a few lithium-ion conductivities reported in literatures are above $1 \mathrm{mS} / \mathrm{cm}$ at $25^{\circ} \mathrm{C}$. A lithium-ion conductivity of about $1.3 \mathrm{mS} / \mathrm{cm}$ for Ga-doped LLZO through normal sintering was obtained by Bernuy-Lopez et al. ${ }^{23}$ and Rettenwander et al. ${ }^{34}$ The lithium-ion conductivity of $\mathrm{Li}_{6.4} \mathrm{La}_{3} \mathrm{Zr}_{1.4} \mathrm{Ta}_{0.6} \mathrm{O}_{12}$ was enhanced to $1.6 \mathrm{mS} / \mathrm{cm}$ by hot-pressing by Du et al. ${ }^{39}$, and the lithium-ion conductivity of $\mathrm{Li}_{6.5} \mathrm{La}_{3} \mathrm{Zr}_{1.5} \mathrm{Ta}_{0.5} \mathrm{O}_{12}$ obtained by spark plasma sintering by Baek et al. ${ }^{40}$ was $1.35 \mathrm{mS} / \mathrm{cm}$, while the value for Al-containing $\mathrm{Li}_{6.4} \mathrm{La}_{3} \mathrm{Zr}_{1.4} \mathrm{Ta}_{0.6} \mathrm{O}_{12}$ obtained by normal sintering was only $~ 1$ 
$\mathrm{mS} / \mathrm{cm}^{14}$.

Fig. 3 shows the temperature dependence of the total conductivities of the $\mathrm{Li}_{7-3 x} \mathrm{Ga}_{x} \mathrm{La}_{3} \mathrm{Zr}_{2} \mathrm{O}_{12}$ samples. Apparently, the conductivities of the samples $(x \geq 0.20)$ with the cubic phase are higher than those of the samples containing both tetragonal and cubic phases. Activation energies are calculated from the slopes of the plots; the activation energy at temperatures lower than $\sim 20{ }^{\circ} \mathrm{C}$ is slightly higher than that at higher temperatures, owing to the "ion trapping effect" at low temperatures, i.e. mobile $\mathrm{Li}^{+}$ions are trapped by immobile negatively charged defects ${ }^{29}$. The activation energies for the overall testing temperature, as well as high and low temperature sides are given in Table 1. The activation energy decreases at first and then increases with increasing Ga content, reaching a minimum of $0.25 \mathrm{eV}$ at $x=0.25$. The low activation energies indicate that lithium ions transport easily in the $\mathrm{Li}_{7-3 x} \mathrm{Ga}_{x} \mathrm{La}_{3} \mathrm{Zr}_{2} \mathrm{O}_{12}$ samples. The activation energy for the $\mathrm{Li}_{7-3 x} \mathrm{Ga}_{x} \mathrm{La}_{3} \mathrm{Zr}_{2} \mathrm{O}_{12}$ samples with the cubic phase, derived from the data in the overall testing temperature, are in the range of 0.25 to $0.28 \mathrm{eV}$, which are amongst the lowest of the LLZO electrolytes in Table 2.

\subsection{Electronic conductivity}

An ideal solid electrolyte must be a purely ionic conductor, because electronic conduction causes electrical leakage or a short circuit in the lithium-ion battery. The DC polarization method was used to measure the electronic conductivity of the samples. DC voltage applied to the sample induces polarization, reaching steady-state over $1000 \mathrm{~s}$ (Fig. 4). Because the Ag electrode is blocking to lithium ions, but not to electrons, the current at the steady state arises only from the electronic conduction. 
The electronic conductivity $\left(\sigma_{\mathrm{e}}\right)$ is on the order of $10^{-8} \mathrm{~S} / \mathrm{cm}$ (Table 1 ), being 4 or 5 orders of magnitude lower than the lithium-ion conductivity. Thus, the transference number of lithium ions $\left(t_{L i}=\frac{\sigma_{\text {total }}-\sigma_{e}}{\sigma_{\text {total }}}\right)$ for the $\mathrm{Li}_{7-3 x} \mathrm{Ga}_{x} \mathrm{La}_{3} \mathrm{Zr}_{2} \mathrm{O}_{12}$ samples is nearly unity.

\subsection{Modulus spectrum analysis}

Complex modulus formalism is an important tool to derive information related to charge-transport processes. The complex electric modulus $\left(M^{*}\right)$ can be calculated from the complex impedance $\left(Z^{*}\right)$ through the relation:

$M^{*}(\omega)=i \omega C_{0} Z^{*}=M^{\prime}(\omega)+i M^{\prime \prime}(\omega)$

where the geometrical capacitance $C_{0}=\varepsilon_{0} A / t$ ( $\varepsilon_{0}$ is the permittivity of free space, $A$ the area of the electrode, and $t$ the sample thickness), and $M^{\prime}$ and $M^{\prime \prime}$ are the real and imaginary parts of the electric modulus, respectively.

Fig. 5 shows the imaginary part of the electric modulus $\left(M^{\prime \prime}\right)$ as a function of frequency for the $\mathrm{Li}_{7-3 x} \mathrm{Ga}_{x} \mathrm{La}_{3} \mathrm{Zr}_{2} \mathrm{O}_{12}$ samples in the temperature range of -60 to $0{ }^{\circ} \mathrm{C}$. The appearance of a peak in the modulus spectrum at low temperatures provides a signal of conductivity relaxation. The low frequency wing below the peak maximum $\left(M_{\max }{ }^{\prime \prime}\right)$ represents the range in which charge carriers are mobile at long distance. On the other hand, at frequencies above the peak maximum the charge carriers are confined to potential wells and mobile at short distance. The peak frequency increases with increasing temperature and the peak disappears at a threshold temperature, e.g., $-50{ }^{\circ} \mathrm{C}$ for $\mathrm{Li}_{6.25} \mathrm{Ga}_{0.25} \mathrm{La}_{3} \mathrm{Zr}_{2} \mathrm{O}_{12}$ and $-30{ }^{\circ} \mathrm{C}$ for $\mathrm{Li}_{5.80} \mathrm{Ga}_{0.40} \mathrm{La}_{3} \mathrm{Zr}_{2} \mathrm{O}_{12}$. The temperature dependence of the peak frequency suggests that hopping dominates the 
relaxation process. Also, the absence of a peak at temperatures $>-50{ }^{\circ} \mathrm{C}$ for $\mathrm{Li}_{6.25} \mathrm{Ga}_{0.25} \mathrm{La}_{3} \mathrm{Zr}_{2} \mathrm{O}_{12}$ suggests that there is only long-range migration.

The peak frequency $f_{\max }$ represents the conductivity relaxation frequency, and $f_{\max } \tau_{\max }=1$, where $\tau_{\max }$ is the characteristic relaxation time, representing the time scale of the transition from long- to short-range mobility. Better information on the bulk conduction properties can be obtained from the Arrhenius plot of $f_{\max }$. In Fig. 5(f), the temperature dependence of $f_{\text {max }}$ for the $\mathrm{Li}_{5.80} \mathrm{Ga}_{0.40} \mathrm{La}_{3} \mathrm{Zr}_{2} \mathrm{O}_{12}$ sample is shown. The activation energy is $0.30 \mathrm{eV}$, very close to that obtained from the Arrhenius plot of the total conductivity in the low temperature range, further evidencing the long-range migration of free lithium ions ${ }^{48,57}$.

\subsection{Concentration and mobility of charge carriers}

The frequency dependence of the real part of the AC conductivity, $\sigma^{\prime}(\omega)$, for the cubic $\mathrm{Li}_{7-3 x} \mathrm{Ga}_{x} \mathrm{La}_{3} \mathrm{Zr}_{2} \mathrm{O}_{12}$ samples at selected temperatures are shown in Fig. 6. The $\sigma^{\prime}(\omega)$ and frequency follow the Jonscher's power law ${ }^{58}$ :

$\sigma^{\prime}(\omega)=\sigma_{d c}+A \omega^{n}=K \omega_{c}\left[1+\left(\frac{\omega}{\omega_{c}}\right)^{n}\right]$

where $\sigma_{d c}$ is the DC ionic conductivity, $\omega$ the angular frequency, $\omega_{c}$ the jumping rate of charge carriers, $A$ and $K$ the pre-factors, and $n$ a dimensionless frequency exponent in the range $0<n<1$. As shown in Fig. 6, one platform at high frequencies, representing the DC ionic conductivity, is found for each curve, and the decrease in the ionic conductivity at low frequencies can be ascribed to the electrode process. The bulk properties are the focus, therefore, the data at high frequencies are fitted according to the Jonscher's power law. The fitting curves are also shown in Fig. 6. 
The DC conductivity and the jump rate $\omega_{\mathrm{c}}$ are calculated from the fitting curves. The concentration of mobile lithium ions is calculated according to the Nernst-Einstein-Smoluchowki equation:

$\sigma_{d c}=e n_{c} \mu=\frac{n_{c} \omega_{c} e^{2} \alpha^{2}}{2 \pi k_{B} T}$

where $n_{c}$ is the concentration of the mobile lithium ions, $\mu$ the mobility of the charge carriers, $\alpha$ the jumping distance $\left(0.2 \mathrm{~nm}\right.$ for LLZO $\left.{ }^{28,29}\right), k_{\mathrm{B}}$ the Boltzmann constant, and $T$ the absolute temperature. The diffusion coefficient $(D)$ is related to the mobility and the DC conductivity through the relationship:

$D=\frac{k_{B} T \mu}{e}=\frac{\sigma_{d c} k_{B} T}{n_{c} e^{2}}$

The typical results for the $\mathrm{Li}_{7-3 x} \mathrm{Ga}_{x} \mathrm{La}_{3} \mathrm{Zr}_{2} \mathrm{O}_{12}$ samples are summarized in Table 3 . The concentration of mobile lithium ions is on the order of $10^{21} \mathrm{~cm}^{-3}$, mobility is on the order of $10^{-7}$ to $10^{-6} \mathrm{~cm}^{2} \mathrm{~V}^{-1} \mathrm{~s}^{-1}$, and the jumping rate is on the order of $10^{7} \mathrm{rad} / \mathrm{s}$ at $-10{ }^{\circ} \mathrm{C}$. The concentration of mobile lithium ions in the $\mathrm{Li}_{7-3 x} \mathrm{Ga}_{x} \mathrm{La}_{3} \mathrm{Zr}_{2} \mathrm{O}_{12}$ samples are comparable with that in pristine and W-doped LLZO ${ }^{28,29}$, while the mobility and jumping rate of mobile lithium ions in the $\mathrm{Li}_{7-3 x} \mathrm{Ga}_{x} \mathrm{La}_{3} \mathrm{Zr}_{2} \mathrm{O}_{12}$ samples are significantly higher. The diffusion coefficients are also higher than those previously reported for lithium ion conductors 28,29 . The high ionic conductivities of the $\mathrm{Li}_{7-3 x} \mathrm{Ga}_{x} \mathrm{La}_{3} \mathrm{Zr}_{2} \mathrm{O}_{12}$ samples can thus be ascribed to the increased mobility of lithium ions.

\subsection{Lithium ion distribution}

Lithium ion distribution at tetrahedral and octahedral sites is a crucial factor determining the overall mobility of lithium ions in LLZO electrolytes, because lithium 
ions at octahedral sites exhibit higher mobility than those at tetrahedral sites ${ }^{29}$.

The initial structure model used in the Rietveld analysis of the NPD data for the $\mathrm{Li}_{7-3 x} \mathrm{Ga}_{x} \mathrm{La}_{3} \mathrm{Zr}_{2} \mathrm{O}_{12}(x=0.20$ and 0.30$)$ samples was taken from Wang et al. ${ }^{29}$ and Chen et al. ${ }^{33}$, in which Ga atoms occupy the $\mathrm{Li}(24 d)$ site $^{23}$. The results of structure refinement are listed in Table 4 and the corresponding Rietveld refinement plots are shown in Fig. 7. Two kinds of lithium ions occupy $24 d$ (tetrahedral) and $96 \mathrm{~h}$ (octahedral) sites, and $96 h$ sites characterize positions that deviate from the center of octahedral $48 g$ sites, with lithium content at the $96 h$ site being higher than that at the $24 d$ site. The other ions ( $\mathrm{La}, \mathrm{Zr}$ and $\mathrm{O}$ ) are at their normal lattice sites.

${ }^{6} \mathrm{Li}$ MAS NMR was used to detect the lithium-ion local environment and dynamics in the $\mathrm{Li}_{7-3 \mathrm{x}} \mathrm{Ga}_{\mathrm{x}} \mathrm{La}_{3} \mathrm{Zr}_{2} \mathrm{O}_{12}$ samples, and corresponding ${ }^{6} \mathrm{Li}$ MAS NMR spectra are shown in Fig. 8(a). The typical chemical shift of lithium at $24 d$ tetrahedral and $48 g$ octahedral sites are 0.8 and $1.9 \mathrm{ppm}$, respectively, and that of lithium at $96 \mathrm{~h}$ octahedral sites is characterized by a low chemical shift ${ }^{29,59}$. Combined with the NPD results, we can conclude that the peaks at around $1.3 \mathrm{ppm}$ in Fig. 8(a) can be attributed to lithium at the $96 h$ site, and this signal overlaps that at $0.8 \mathrm{ppm}$ arising from lithium ions at the $24 d$ site. It is difficult to quantitatively determine lithium content at tetrahedral and octahedral sites by fitting these overlapped peaks. Fortunately, the spin-lattice relaxation time $\left(T_{1}\right)$ of lithium is also sensitive to the local environment. Fig. 8(b) shows the saturation recovery of the ${ }^{6} \mathrm{Li}$ signal, and a bi-exponential function describes the data well. The fitting reveals a main component $(\sim 92 \%)$ with smaller $T_{1}(t 2=1.72186 \mathrm{~s})$ arising from lithium at octahedral sites and 
minor component with larger $T_{1}(t 1=60.8798 \mathrm{~s})$ arising from lithium at tetrahedral sites. The smaller $T_{1}$ of lithium at the $96 h$ octahedral site suggests a higher mobility.

From the NPD and ${ }^{6} \mathrm{Li}$ MAS NMR results, it is clear that more lithium resides at octahedral than tetrahedral sites. Lithium at the $96 h$ site is not centrally located within the octahedron (Fig. 9). Electrostatic repulsion, including $\mathrm{Li}^{+}-\mathrm{Li}^{+}$and $\mathrm{Li}^{+}-$dopant pairs, causes the redistribution of lithium between tetrahedral and octahedral sites, and the $\mathrm{Li}^{+}$- dopant repulsion also influences the lithium at neighboring sites ${ }^{33}$. Therefore, the strong coulombic repulsion between immobile $\mathrm{Ga}^{3+}$ and the nearby lithium ions shifts lithium away from their central position within the octahedron in the $\mathrm{Li}_{7-3 x} \mathrm{Ga}_{x} \mathrm{La}_{3} \mathrm{Zr}_{2} \mathrm{O}_{12}$ garnets. The lithium-ion distribution in $\mathrm{Li}_{7-3 x} \mathrm{Ga}_{x} \mathrm{La}_{3} \mathrm{Zr}_{2} \mathrm{O}_{12}$ is therefore significantly different to that in the $\mathrm{Te}$ or $\mathrm{W}$ doped garnets, where a large number of lithium ions are located at $48 g$ sites ${ }^{16,29}$. Hence, the high lithium-ion conductivity of $\mathrm{Li}_{7-3 x} \mathrm{Ga}_{x} \mathrm{La}_{3} \mathrm{Zr}_{2} \mathrm{O}_{12}$ electrolytes can be ascribed to enhanced mobility of lithium ions arising from the coulombic repulsion between $\mathrm{Ga}^{3+}$ and $\mathrm{Li}^{+}$ions. This could also explain the relatively low activation energies for conductivity in the $\mathrm{Li}_{7-3 x} \mathrm{Ga}_{x} \mathrm{La}_{3} \mathrm{Zr}_{2} \mathrm{O}_{12}$ system.

In cubic LLZO, lithium ions can transport along tetrahedral and octahedral sites, with the possibility for lithium exchange between the sites as a consequence of vacancies at both sites ${ }^{29}$. Generally, the direct lithium-ion transport along tetrahedral sites is difficult; Li NMR and dielectric loss spectroscopy measurements suggest a pathway of $48 g / 96 h-48 g / 96 h$ involving only octahedral sites 57, 59-61. However, anisotropic atomic displacement parameters obtained using neutron diffraction, 
maximum entropy methods and two-dimensional ${ }^{6} \mathrm{Li}-{ }^{6} \mathrm{Li}$ exchange NMR spectra, suggest that the diffusion occurs through the pathway $24 d-48 g / 96 h-24 d^{29,62,63}$. As the jumping rate of lithium at tetrahedral sites is lower than that at octahedral sites, the lithium-ion migration rate through the $24 d-96 h-24 d$ pathway is limited by the jumping rate of lithium at tetrahedral sites. In the $24 d-96 h-24 d$ pathway, $\mathrm{Ga}^{3+}$ ions have little impact on lithium-ion mobility, because they are separated from lithium at tetrahedral sites by Li at octahedral sites (Fig. 9). However, the mobility of lithium ions in the $\mathrm{Li}_{7-3 x} \mathrm{Ga}_{\mathrm{x}} \mathrm{La}_{3} \mathrm{Zr}_{2} \mathrm{O}_{12}$ samples is greatly enhanced by $\mathrm{Ga}$, relative to both pristine and W-doped LLZO ${ }^{28,29}$. As found in the work of Wang et al. ${ }^{29}$, the ${ }^{6} \mathrm{Li}-{ }^{6} \mathrm{Li}$ exchange signal, characterizing lithium-ion transport between the two different sites, indicated the lithium-ion transport along octahedral sites. Wagner et al. ${ }^{26}$ also proposed an additional lithium-ion diffusion pathway in the $\mathrm{Ga}^{3+}$ doped garnets, as informed by ${ }^{7}$ Li NMR spin-lattice relaxation rates. Taken together, there are two migration pathways (Fig. 9(c)) in the $\mathrm{Li}_{7-3 x} \mathrm{Ga}_{x} \mathrm{La}_{3} \mathrm{Zr}_{2} \mathrm{O}_{12}$ garnets: $24 d-96 h-24 d$ and $96 h-96 h$; however, the migration rate of lithium ions between $96 h-96 h$ sites is much higher.

\section{Conclusions}

The present study thoroughly investigates the influence of Ga doping on the properties of $\mathrm{Li}_{7-3 x} \mathrm{Ga}_{x} \mathrm{La}_{3} \mathrm{Zr}_{2} \mathrm{O}_{12}$ garnets. The minimum concentration of $\mathrm{Ga}$ required for stabilizing the cubic phase is found to be $0.20 \mathrm{Ga}$ per formula unit, below which both cubic and tetragonal phases coexist. In the $\mathrm{Li}_{7-3 x} \mathrm{Ga}_{x} \mathrm{La}_{3} \mathrm{Zr}_{2} \mathrm{O}_{12}$ garnets, lithium ions predominantly occupy the $96 h$ site, which is non-central within the octahedron as a result of coulombic repulsion between $\mathrm{Ga}^{3+}$ and $\mathrm{Li}^{+}$. The remaining $\mathrm{Li}$ is found at 
the tetrahedral site. The highest lithium-ion conductivity of $1.46 \mathrm{mS} / \mathrm{cm}$ at $25{ }^{\circ} \mathrm{C}$ is found at a Ga concentration of 0.25 per formula unit, at which the activation energy for conductivity reaches its minimum of $0.25 \mathrm{eV}$. The enhancement of conductivity by Ga can be ascribed to a high mobility of lithium ions arising from the coulombic repulsion between $\mathrm{Ga}^{3+}$ and $\mathrm{Li}^{+}$. This work opens the door to the strategic doping of other electrolytes to enhance ionic conductivity.

\section{Acknowledgements}

This work is supported by the National Natural Science Foundation of China (Grant No. 51672096). Dr. Wei Kong Pang is grateful for the financial support of the Australian Research Council (FT160100251). 


\section{References}

1. Tarascon, J. M.; Armand, M., Issues and Challenges Facing Rechargeable Lithium Batteries Nature 2001, 414, 359-367.

2. Armand, M.; Tarascon, J. M., Building Better Batteries Nature 2008, 451, 652-657.

3. Kamaya, N.; Homma, K.; Yamakawa, Y.; Hirayama, M.; Kanno, R.; Yonemura, M.; Kamiyama, T.; Kato, Y.; Hama, S.; Kawamoto, K.; Mitsui, A., A Lithium Superionic Conductor Nat. Mater. 2011, 10, 682-686.

4. Kato, Y.; Hori, S.; Saito, T.; Suzuki, K.; Hirayama, M.; Mitsui, A.; Yonemura, M.; Iba, H.; Kanno, R., High-power All-solid-state Batteries Using Sulfide Superionic Conductors Nat. Energy 2016, 1, 16030.

5. Bachman, J. C.; Muy, S.; Grimaud, A.; Chang, H. H.; Pour, N.; Lux, S. F.; Paschos, O.; Maglia, F.; Lupart, S.; Lamp, P.; Giordano, L.; Shao-Horn, Y., Inorganic Solid-state Electrolytes for Lithium Batteries: Mechanisms and Properties Governing Ion Conduction Chem. Rev. 2016, 116, 140-162.

6. Takada, K., Progress and Prospective of Solid-state Lithium Batteries Acta Mater. 2013, 61, 759-770.

7. Kalaga, K.; Rodrigues, M.-T. F.; Gullapalli, H.; Babu, G.; Arava, L. M. R.; Ajayan, P. M., Quasi-Solid Electrolytes for High Temperature Lithium Ion Batteries ACS Appl. Mater. Interfaces 2015, 7, 25777-25783.

8. Thangadurai, V.; Narayanan, S.; Pinzaru, D., Garnet-type Solid-state Fast Li Ion Conductors for Li Batteries: Critical Review Chem. Soc. Rev. 2014, 43, 4714-4727.

9. Luo, W.; Gong, Y.; Zhu, Y.; Fu, K. K.; Dai, J.; Lacey, S. D.; Wang, C.; Liu, B.; Han, X.; Mo, Y.; Wachsman, E. D.; Hu, L., Transition from Super-lithiophobicity to Super-lithiophilicity of Garnet 
Solid-state Electrolyte J. Am. Chem. Soc. 2016, 138, 12258-12262.

10. Fua, K. K.; Gonga, Y.; Daib, J.; Gong, A.; Han, X.; Yao, Y.; Wang, C.; Wang, Y.; Chen, Y.; Yan, C.;

Li, Y.; Wachsman, E. D.; Hu, L., Flexible, Solid-state, Ion-conducting Membrane with 3D Garnet Nanofiber Networks for Lithium Batteries Proc. Natl. Acad. Sci. USA 2016, 113, 7094-7099.

11. Murugan, R.; Thangadurai, V.; Weppner, W., Fast Lithium Ion Conduction in Garnet-type $\mathrm{Li}_{7} \mathrm{La}_{3} \mathrm{Zr}_{2} \mathrm{O}_{12}$ Angew. Chem. Int. Ed. 2007, 46, 7778-7781.

12. Geiger, C. A.; Alekseev, E.; Lazic, B.; Fisch, M.; Armbruster, T.; Langner, R.; Fechtelkord, M.; Kim, N.; Pettke, T.; Weppner, W., Crystal Chemistry and Stability of " $\mathrm{Li}_{7} \mathrm{La}_{3} \mathrm{Zr}_{2} \mathrm{O}_{12}$ " Garnet: a Fast Lithium-ion Conductor Inorg. Chem. 2011, 50, 1089-1097.

13. Bernstein, N.; Johannes, M. D.; Hoang, K., Origin of the Structure Phase Transition in $\mathrm{Li}_{7} \mathrm{La}_{3} \mathrm{Zr}_{2} \mathrm{O}_{12}$ Phys. Rev. Lett. 2012, 109, 205702-205706.

14. Li, Y.; Han, J.-T.; Wang, C.-A.; Xie, H.; Goodenough, J. B., Optimizing $\mathrm{Li}^{+}$Conductivity in a Garnet Framework J. Mater. Chem. 2012, 22, 15357-15361.

15. Huang, M.; Shoji, M.; Shen, Y.; Nan, C.-W.; Munakata, H.; Kanamura, K., Preparation and Electrochemical Properties of $\mathrm{Zr}$-site Substituted $\mathrm{Li}_{7} \mathrm{La}_{3}\left(\mathrm{Zr}_{2-\mathrm{x}} \mathrm{M}_{\mathrm{x}}\right) \mathrm{O}_{12}(\mathrm{M}=\mathrm{Ta}, \mathrm{Nb})$ Solid Electrolytes $\mathrm{J}$. Power Sources 2014, 261, 206-211.

16. Wang, D.; Zhong, G.; Dolotko, O.; Li, Y.; McDonald, M. J.; Mi, J.-X.; Fu, R.; Yang, Y., The Synergistic Effects of $\mathrm{Al}$ and $\mathrm{Te}$ on the Structure and $\mathrm{Li}^{+}$-mobility of the Garnet-type Solid Electrolytes J. Mater. Chem. A 2014, 2, 20271-20279.

17. Li, Y.; Wang, Z.; Cao, Y.; Du, F.; Chen, C.; Cui, Z.; Guo, X., W-doped $\mathrm{Li}_{7} \mathrm{La}_{3} \mathrm{Zr}_{2} \mathrm{O}_{12}$ Ceramic Electrolytes for Solid State Li-ion Batteries Electrochim. Acta 2015, 180, 37-42.

18. Wolfenstine, J.; Ratchford, J.; Rangasamy, E.; Sakamoto, J.; Allen, J. L., Synthesis and High 
Li-ion Conductivity of Ga-stabilized Cubic $\mathrm{Li}_{7} \mathrm{La}_{3} \mathrm{Zr}_{2} \mathrm{O}_{12}$ Mater. Chem. Phys. 2012, 134, 571-575.

19. Allen, J. L.; Wolfenstine, J.; Rangasamy, E.; Sakamoto, J., Effect of Substitution (Ta, Al, Ga) on the Conductivity of $\mathrm{Li}_{7} \mathrm{La}_{3} \mathrm{Zr}_{2} \mathrm{O}_{12}$ J. Power Sources 2012, 206, 315-319.

20. Howard, M. A.; Clemens, O.; Kendrick, E.; Knight, K. S.; Apperley, D. C.; Anderson, P. A.; Slater, P. R., Effect of Ga Incorporation on the Structure and $\mathrm{Li}$ Ion conductivity of $\mathrm{Li}_{7} \mathrm{La}_{3} \mathrm{Zr}_{2} \mathrm{O}_{12}$ Dalton Trans. 2012, 41, 12048-12053.

21. El Shinawi, H.; Janek, J., Stabilization of Cubic Lithium-stuffed Garnets of the Type " $\mathrm{Li}_{7} \mathrm{La}_{3} \mathrm{Zr}_{2} \mathrm{O}_{12}$ " by Addition of Gallium J. Power Sources 2013, 225, 13-19.

22. Jalem, R.; Rushton, M.; Manalastas, W.; Nakayama, M.; Kasuga, T.; Kilner, J. A.; Grimes, R. W., Effects of Gallium Doping in Garnet-type $\mathrm{Li}_{7} \mathrm{La}_{3} \mathrm{Zr}_{2} \mathrm{O}_{12}$ Solid Electrolytes Chem. Mater. 2015, 27, 2821-2831.

23. Bernuy-Lopez, C.; Manalastas, W.; Lopez del Amo, J. M.; Aguadero, A.; Aguesse, F.; Kilner, J. A., Atmosphere Controlled Processing of Ga-substituted Garnets for High Li-ion Conductivity Ceramics Chem. Mater. 2014, 26, 3610-3617.

24. Rettenwander, D.; Geiger, C. A.; Tribus, M.; Tropper, P.; Amthauer, G., A Synthesis and Crystal Chemical Study of the Fast Ion Conductor $\mathrm{Li}_{7-3 x} \mathrm{Ga}_{x} \mathrm{La}_{3} \mathrm{Zr}_{2} \mathrm{O}_{12}$ with $\mathrm{x}=0.08$ to 0.84 Inorg. Chem. 2014, 53, 6264-6269.

25. Rettenwander, D.; Langer, J.; Schmidt, W.; Arrer, C.; Harris, K. J.; Terskikh, V.; Goward, G. R.; Wilkening, M.; Amthauer, G., On the Site Occupation of Ga and Al in Stabilized Cubic $\mathrm{Li}_{7-3(x+y)} \mathrm{Ga}_{\mathrm{x}} \mathrm{Al}_{\mathrm{y}} \mathrm{La}_{3} \mathrm{Zr}_{2} \mathrm{O}_{12}$ Garnets as Deduced from ${ }^{27} \mathrm{Al}$ and ${ }^{71} \mathrm{Ga}$ MAS NMR at Ultrahigh Magnetic Fields Chem. Mater. 2015, 27, 2821-2831.

26. Wagner, R.; Redhammer, G. J.; Rettenwander, D.; Senyshyn, A.; Schmidt, W.; Wilkening, M.; 
Amthauer, G., Crystal Structure of Garnet-related Li-ion Conductor $\mathrm{Li}_{7-3 \mathrm{x}} \mathrm{Ga}_{\mathrm{x}} \mathrm{La}_{3} \mathrm{Zr}_{2} \mathrm{O}_{12}$ : Fast Li-ion Conduction Caused by a Different Cubic Modification? Chem. Mater. 2016, 28, 1861-1871.

27. Xie, H.; Alonso, J. A.; Li, Y.; Fernández-Díaz, M. T.; Goodenough, J. B., Lithium Distribution in Aluminum-free Cubic $\mathrm{Li}_{7} \mathrm{La}_{3} \mathrm{Zr}_{2} \mathrm{O}_{12}$ Chem. Mater. 2011, 23, 3587-3589.

28. Ahmad, M. M., Estimation of the Concentration and Mobility of Mobile $\mathrm{Li}^{+}$in the Cubic Garnet-type $\mathrm{Li}_{7} \mathrm{La}_{3} \mathrm{Zr}_{2} \mathrm{O}_{12}$ RSC Adv. 2015, 5, 25824-25829.

29. Wang, D.; Zhong, G.; Pang, W. K.; Guo, Z.; Li, Y.; McDonald, M. J.; Fu, R.; Mi, J.-X.; Yang, Y., Towards Understanding the Lithium Transport Mechanism in Garnet-type Solid Electrolytes: $\mathrm{Li}^{+}$Ions Exchanges and Their Mobility at Octahedral/Tetrahedral Sites Chem. Mater. 2015, 27, 6650-6659.

30. Bucheli, W.; Duran, T.; Jimenez, R.; Sanz, J.; Varez, A., On the Influence of the Vacancy Distribution on the Structure and Ionic Conductivity of A-site-deficient $\mathrm{Li}_{\mathrm{x}} \mathrm{Sr}_{\mathrm{x}} \mathrm{La}_{2 / 3-\mathrm{x}} \mathrm{TiO}_{3} \mathrm{Perovskites}$ Inorg. Chem. 2012, 51, 5831-5838.

31. Zeier, W. G., Structural Limitations for Optimizing Garnet-type Solid Electrolytes: A Perspective Dalton Trans. 2014, 43, 16133-16138

32. Thompson, T.; Sharafi, A.; Johannes, M. D.; Huq, A.; Allen, J. L.; Wolfenstine, J.; Sakamoto, J., A Tale of Two Sites: On Defining the Carrier Concentration in Garnet-based Ionic Conductors for Advanced Li Batteries Adv. Energy Mater. 2015, 5, 1500096-1500104.

33. Chen, Y.; Rangasamy, E.; Liang, C.; An, K., Origin of High $\mathrm{Li}^{+}$Conduction in Doped $\mathrm{Li}_{7} \mathrm{La}_{3} \mathrm{Zr}_{2} \mathrm{O}_{12}$ Garnets Chem. Mater. 2015, 27, 5491-5494.

34. Rettenwander, D.; Redhammer, G.; Preishuber-Pflügl, F.; Cheng, L.; Miara, L.; Wagner, R.; Welzl, A.; Suard, E.; Doeff, M. M.; Wilkening, M.; Fleig, J.; Amthauer, G., Structural and Electrochemical Consequences of $\mathrm{Al}$ and $\mathrm{Ga}$ Co-substitution in $\mathrm{Li}_{7} \mathrm{La}_{3} \mathrm{Zr}_{2} \mathrm{O}_{12}$ Solid Electrolytes Chem. Mater. 2016, 28, 
$2384-2392$.

35. Liss, K. D.; Hunter, B.; Hagen, M.; Noakes, T.; Kennedy, S., The New High-Resolution Powder Diffractometer Being Built at OPAL Physica B 2006, 385-386, 1010-1012.

36. Toby, B. H.; Von Dreele, R. B., GSAS-II: the Genesis of a Modern Open-source All Purpose Crystallography Software Package J. Appl. Cryst. 2013, 46, 544-549.

37. Tietz, F.; Wegener, T.; Gerhards, M. T.; Giarola, M.; Mariotto, G., Synthesis and Raman Micro-spectroscopy Investigation of $\mathrm{Li}_{7} \mathrm{La}_{3} \mathrm{Zr}_{2} \mathrm{O}_{12}$ Solid State Ionics 2013, 230, 77-82.

38. Thompson, T.; Wolfenstine, J.; Allen, J. L.; Johannes, M.; Huq, A.; David, I. N.; Sakamoto, J., Tetragonal vs. Cubic Phase Stability in Al - free Ta Doped $\mathrm{Li}_{7} \mathrm{La}_{3} \mathrm{Zr}_{2} \mathrm{O}_{12}$ (LLZO) J. Mater. Chem. A 2014, 2, 13431-13436.

39. Du, F.; Zhao, N.; Li, Y.; Chen, C.; Liu, Z.; Guo, X., All Solid State Lithium Batteries Based on Lamellar Garnet-type Ceramic Electrolytes J. Power Sources 2015, 300, 24-28.

40. Baek, S.-W.; Lee, J.-M.; Kim, T. Y.; Song, M.-S.; Park, Y., Garnet Related Lithium Ion Conductor Processed by Spark Plasma Sintering for All Solid State Batteries J. Power Sources 2014, 249, 197-206.

41. Li, Y.; Wang, Z.; Li, C.; Cao, Y.; Guo, X., Densification and Ionic-conduction Improvement of Lithium Garnet Solid Electrolytes by Flowing Oxygen Sintering J. Power Sources 2014, 248, 642-646.

42. Tong, X.; Thangadurai, V.; Wachsman, E. D., Highly Conductive Li Garnets by a Multielement Doping Strategy Inorg. Chem. 2015, 54, 3600-3607.

43. Wang, Y.; Lai, W., High Ionic Conductivity Lithium Garnet Oxides of $\mathrm{Li}_{7-\mathrm{x}} \mathrm{La}_{3} \mathrm{Zr}_{2-\mathrm{x}} \mathrm{Ta}_{\mathrm{x}} \mathrm{O}_{12}$ Compositions Electrochem. Solid ST 2012, 15, A68-A71.

44. Li, Y.; Wang, C.-A.; Xie, H.; Cheng, J.; Goodenough, J. B., High Lithium Ion Conduction in 
Garnet-type $\mathrm{Li}_{6} \mathrm{La}_{3} \mathrm{ZrTaO}_{12}$ Electrochem. Commun. 2011, 13, 1289-1292.

45. Ren, Y.; Deng, H.; Chen, R.; Shen, Y.; Lin, Y.; Nan, C.-W., Effects of Li Source on Microstructure and Ionic Conductivity of Al-contained $\mathrm{Li}_{6.75} \mathrm{La}_{3} \mathrm{Zr}_{1.75} \mathrm{Ta}_{0.25} \mathrm{O}_{12}$ Ceramics J. Eur. Ceram. Soc. 2015, 35, 561-572

46. Janani, N.; Deviannapoorani, C.; Dhivya, L.; Murugan, R., Influence of Sintering Additives on Densification and $\mathrm{Li}^{+}$Conductivity of $\mathrm{Al}$ doped $\mathrm{Li}_{7} \mathrm{La}_{3} \mathrm{Zr}_{2} \mathrm{O}_{12}$ Lithium Garnet RSC Adv. 2014, 4, 51228-51238.

47. Dhivya, L.; Murugan, R., Effect of Simultaneous Substitution of Y and Ta on the Stabilization of Cubic Phase, Microstructure, and Li Conductivity of $\mathrm{Li}_{7} \mathrm{La}_{3} \mathrm{Zr}_{2} \mathrm{O}_{12}$ Lithium Garnet ACS Appl. Mater. Interfaces 2014, 6, 17606-17615.

48. Deviannapoorani, C.; Dhivya, L.; Ramakumar, S.; Murugan, R., Lithium Ion Transport Properties of High Conductive Tellurium Substituted $\mathrm{Li}_{7} \mathrm{La}_{3} \mathrm{Zr}_{2} \mathrm{O}_{12}$ Cubic Lithium Garnets J. Power Sources 2013, $240,18-25$.

49. Ohta, S.; Kobayashi, T.; Asaoka, T., High Lithium Ionic Conductivity in the Garnet-type Oxide $\mathrm{Li}_{7-\mathrm{x}} \mathrm{La}_{3}\left(\mathrm{Zr}_{2-\mathrm{X}}, \mathrm{Nb}_{\mathrm{X}}\right) \mathrm{O}_{12}(\mathrm{X}=0-2) \mathrm{J}$. Power Sources 2011, 196, 3342-3345.

50. Tadanaga, K.; Takano, R.; Ichinose, T.; Mori, S.; Hayashi, A.; Tatsumisago, M., Low Temperature Synthesis of Highly Ion Conductive $\mathrm{Li}_{7} \mathrm{La}_{3} \mathrm{Zr}_{2} \mathrm{O}_{12}-\mathrm{Li}_{3} \mathrm{BO}_{3}$ Composites Electrochem. Commun. 2013, 33, 51-54.

51. Sakamoto, J.; Rangasamy, E.; Kim, H.; Kim, Y.; Wolfenstine, J., Synthesis of Nano-scale Fast Ion Conducting Cubic $\mathrm{Li}_{7} \mathrm{La}_{3} \mathrm{Zr}_{2} \mathrm{O}_{12}$ Nanotechnology 2013, 24, 424005.

52. Raskovalov, A. A.; Il'ina, E. A.; Antonov, B. D., Structure and Transport Properties of $\mathrm{Li}_{7} \mathrm{La}_{3} \mathrm{Zr}_{2-0.75 x} \mathrm{Al}_{\mathrm{x}} \mathrm{O}_{12}$ Superionic Solid Electrolytes J. Power Sources 2013, 238, 48-52. 
53. Huang, M.; Dumon, A.; Nan, C.-W., Effect of Si, In and Ge Doping on High Ionic Conductivity of $\mathrm{Li}_{7} \mathrm{La}_{3} \mathrm{Zr}_{2} \mathrm{O}_{12}$ Electrochem. Commun. 2012, 21, 62-64.

54. Murugan, R.; Ramakumar, S.; Janani, N., High Conductive Yttrium Doped $\mathrm{Li}_{7} \mathrm{La}_{3} \mathrm{Zr}_{2} \mathrm{O}_{12}$ Cubic Lithium Garnet Electrochem. Commun. 2011, 13, 1373-1375.

55. Jin, Y.; McGinn, P. J., Al-doped $\mathrm{Li}_{7} \mathrm{La}_{3} \mathrm{Zr}_{2} \mathrm{O}_{12}$ Synthesized by a Polymerized Complex Method J. Power Sources 2011, 196, 8683-8687.

56. David, I. N.; Thompson, T.; Wolfenstine, J.; Allen, J. L.; Sakamoto, J.; Viyas, B., Microstructure and Li-ion Conductivity of Hot-pressed Cubic $\mathrm{Li}_{7} \mathrm{La}_{3} \mathrm{Zr}_{2} \mathrm{O}_{12}$ J. Am. Ceram. Soc. 2015, 98, 1209-1214.

57. Baral, A. K.; Narayanan, S.; Ramezanipour, F.; Thangadurai, V., Evaluation of Fundamental Transport Properties of Li-excess Garnet-type $\mathrm{Li}_{5+2 x} \mathrm{La}_{3} \mathrm{Ta}_{2-\mathrm{x}} \mathrm{Y}_{\mathrm{x}} \mathrm{O}_{12}(x=0.25,0.5$ and 0.75$)$ Electrolytes Using AC Impedance and Dielectric Spectroscopy Phys. Chem. Chem. Phys. 2014, 16, 11356-11365.

58. Jonscher, A. K., Dielectric Relaxation in Solids Chelsea Dielectric Press: London, 1983.

59. Kuhn, A.; Narayanan, S.; Spencer, L.; Goward, G.; Thangadurai, V.; Wilkening, M., Li Self-diffusion in Garnet-type $\mathrm{Li}_{7} \mathrm{La}_{3} \mathrm{Zr}_{2} \mathrm{O}_{12}$ as Probed Directly by Diffusion-induced ${ }^{7} \mathrm{Li}$ Spin-lattice Relaxation NMR Spectroscopy Phy. Rev. B 2011, 83, 094302-094312.

60. van Wullen, L.; Echelmeyer, T.; Meyer, H. W.; Wilmer, D., The Mechanism of Li-ion Transport in the Garnet $\mathrm{Li}_{5} \mathrm{La}_{3} \mathrm{Nb}_{2} \mathrm{O}_{12}$ Phys. Chem. Chem. Phys. 2007, 9, 3298-3303.

61. Nyman, M.; Alam, T. M.; McIntyre, S. K.; Bleier, G. C.; Ingersoll, D., Alternative Approach to Increasing Li Mobility in Li-La-Nb/Ta Garnet Electrolytes Chem. Mater. 2010, 22, 5401-5410.

62. Han, J.; Zhu, J.; Li, Y.; Yu, X.; Wang, S.; Wu, G.; Xie, H.; Vogel, S. C.; Izumi, F.; Momma, K.; Kawamura, Y.; Huang, Y.; Goodenough, J. B.; Zhao, Y., Experimental Visualization of Lithium Conduction Pathways in Garnet-type $\mathrm{Li}_{7} \mathrm{La}_{3} \mathrm{Zr}_{2} \mathrm{O}_{12}$ Chem. Commun. 2012, 48, 9840-9842. 
63. Zeier, W. G.; Zhou, S.; Lopez-Bermudez, B.; Page, K.; Melot, B. C., Dependence of the Li-ion Conductivity and Activation Energies on the Crystal Structure and Ionic Radii in $\mathrm{Li}_{6} \mathrm{MLa}_{2} \mathrm{Ta}_{2} \mathrm{O}_{12}$ ACS Appl. Mater. Interfaces 2014, 6, 10900-10907. 
Table 1. Chemical composition, relative density, total conductivity, activation energy, and electronic conductivity of $\mathrm{Li}_{7-3 x} \mathrm{Ga}_{\mathbf{x}} \mathrm{La}_{3} \mathrm{Zr}_{2} \mathrm{O}_{12} \mathrm{samples}$

\begin{tabular}{|c|c|c|c|c|c|c|c|c|}
\hline \multirow{2}{*}{$x$} & \multicolumn{2}{|c|}{ Li:La:Zr:Ga } & \multirow{2}{*}{ Relative density (\%) } & \multirow{2}{*}{$\sigma_{\text {total }}(\mathrm{mS} / \mathrm{cm})$} & \multicolumn{3}{|c|}{$E_{\mathrm{a}}(\mathrm{eV})$} & \multirow{2}{*}{$\sigma_{\text {electronic }}\left(10^{-7} \mathrm{~S} / \mathrm{cm}\right)$} \\
\hline & Nominal & ICP-OES result $^{\mathrm{a}}$ & & & Overall & High $T$ & Low $T$ & \\
\hline 0.10 & $6.70: 3: 2: 0.10$ & -- & 86.7 & 0.025 & 0.34 & - & - & -- \\
\hline 0.15 & $6.55: 3: 2: 0.15$ & -- & 89.6 & 0.085 & 0.33 & - & - & -- \\
\hline 0.20 & $6.30: 3: 2: 0.20$ & 7.02:3:1.95:0.19 & 93.4 & 0.87 & 0.28 & 0.26 & 0.28 & 1.4 \\
\hline 0.25 & $6.25: 3: 2: 0.25$ & $6.79: 3: 1.97: 0.25$ & 94.1 & 1.46 & 0.25 & 0.20 & 0.26 & 0.54 \\
\hline 0.30 & $6.10: 3: 2: 0.30$ & $6.32: 3: 1.96: 0.29$ & 96.3 & 1.12 & 0.25 & 0.23 & 0.25 & 0.47 \\
\hline 0.35 & $5.95: 3: 2: 0.35$ & 6.43:3:1.99:0.33 & 95.1 & 0.71 & 0.26 & 0.24 & 0.27 & 0.81 \\
\hline 0.40 & $5.80: 3: 2: 0.40$ & $6.64: 3: 2.02: 0.42$ & 92.8 & 0.57 & 0.26 & 0.26 & 0.26 & 1.1 \\
\hline
\end{tabular}

${ }^{a}$ Atomic ratio of Li:La:Zr:Ga is normalized by La content in the formula $\mathrm{Li}_{7-3 x} \mathrm{Ga}_{x} \mathrm{La}_{3} \mathrm{Zr}_{2} \mathrm{O}_{12}$. 
Table 2. Electrical properties of LLZO electrolytes

\begin{tabular}{|c|c|c|c|c|c|}
\hline Composition & $\begin{array}{c}\text { Relative } \\
\text { density (\%) }\end{array}$ & $\begin{array}{c}\sigma_{\text {total }} \\
(\mathrm{mS} / \mathrm{cm})\end{array}$ & $\begin{array}{c}\text { Temperature } \\
\left({ }^{\circ} \mathrm{C}\right)\end{array}$ & $\begin{array}{c}E_{\mathrm{a}} \\
(\mathrm{eV})\end{array}$ & Ref. \\
\hline $\mathrm{Li}_{6.25} \mathrm{Ga}_{0.25} \mathrm{La}_{3} \mathrm{Zr}_{2} \mathrm{O}_{12}$ & 94.1 & 1.46 & 25 & 0.25 & $\begin{array}{c}\text { this } \\
\text { work }\end{array}$ \\
\hline $\mathrm{Li}_{6.4} \mathrm{Ga}_{0.2} \mathrm{La}_{3} \mathrm{Zr}_{2} \mathrm{O}_{12}$ & -- & 1.32 & 20 & 0.256 & [34] \\
\hline $\mathrm{Li}_{6.55} \mathrm{Ga}_{0.15} \mathrm{La}_{3} \mathrm{Zr}_{2} \mathrm{O}_{12}$ & \multirow{2}{*}{--} & 1.3 & \multirow{2}{*}{25} & \multirow{2}{*}{0.30} & \multirow{2}{*}{ [23] } \\
\hline $\mathrm{Li}_{6.6} \mathrm{Ga}_{0.2} \mathrm{La}_{3} \mathrm{Zr}_{2} \mathrm{O}_{12}$ & & 0.9 & & & \\
\hline $\mathrm{Li}_{7} \mathrm{Ga}_{1.0} \mathrm{La}_{3} \mathrm{Zr}_{2} \mathrm{O}_{12}$ & 92.5 & 0.54 & 20 & $0.32 \sim 0.37$ & [21] \\
\hline $\mathrm{Li}_{6.25} \mathrm{Ga}_{0.25} \mathrm{La}_{3} \mathrm{Zr}_{2} \mathrm{O}_{12}$ & -- & 0.35 & -- & -- & [18] \\
\hline $\mathrm{Li}_{6.15} \mathrm{Ga}_{0.2} \mathrm{La}_{3} \mathrm{Zr}_{1.75} \mathrm{Ta}_{0.25} \mathrm{O}_{12}$ & $96 \sim 98$ & 0.41 & \multirow{2}{*}{25} & 0.27 & \multirow{2}{*}{ [19] } \\
\hline $\mathrm{Li}_{6.15} \mathrm{Al}_{0.2} \mathrm{La}_{3} \mathrm{Zr}_{1.75} \mathrm{Ta}_{0.25} \mathrm{O}_{12}$ & & 0.37 & & 0.30 & \\
\hline $\mathrm{Li}_{6.4} \mathrm{La}_{3} \mathrm{Zr}_{1.4} \mathrm{Ta}_{0.6} \mathrm{O}_{12}$ & 99.6 & 1.6 & 25 & 0.26 & [39] \\
\hline $\mathrm{Li}_{7-\mathrm{x}} \mathrm{La}_{3} \mathrm{Zr}_{1.5} \mathrm{Ta}_{0.5} \mathrm{O}_{12}$ & -- & 1.35 & 25 & 0.36 & [40] \\
\hline $\mathrm{Li}_{6.75} \mathrm{La}_{3} \mathrm{Zr}_{1.75} \mathrm{Ta}_{0.25} \mathrm{O}_{12}$ & -- & 0.74 & 25 & 0.33 & [41] \\
\hline $\mathrm{Li}_{6.4} \mathrm{La}_{3} \mathrm{Zr}_{1.4} \mathrm{Ta}_{0.6} \mathrm{O}_{12}$ & -- & 0.724 & 25 & 0.24 & [42] \\
\hline $\mathrm{Li}_{6.8} \mathrm{La}_{3} \mathrm{Zr}_{1.8} \mathrm{Ta}_{0.2} \mathrm{O}_{12}$ & -- & 0.69 & $\mathrm{RT}$ & $\sim 0.36$ & [43] \\
\hline $\mathrm{Li}_{6} \mathrm{La}_{3} \mathrm{ZrTaO}_{12}$ & -- & 0.18 & 25 & 0.42 & [44] \\
\hline Al-doped $\mathrm{Li}_{6.4} \mathrm{La}_{3} \mathrm{Zr}_{1.4} \mathrm{Ta}_{0.6} \mathrm{O}_{12}$ & -- & $\sim 1$ & \multirow{3}{*}{25} & 0.35 & \multirow{3}{*}{ [14] } \\
\hline Al-doped $\mathrm{Li}_{6.5} \mathrm{La}_{3} \mathrm{Zr}_{1.5} \mathrm{Ta}_{0.5} \mathrm{O}_{12}$ & & 0.92 & & -- & \\
\hline Al-doped $\mathrm{Li}_{6.6} \mathrm{La}_{3} \mathrm{Zr}_{1.6} \mathrm{Ta}_{0.4} \mathrm{O}_{12}$ & & 0.73 & & -- & \\
\hline Al-doped $\mathrm{Li}_{6.75} \mathrm{La}_{2} \mathrm{Zr}_{1.75} \mathrm{Ta}_{0.25} \mathrm{O}_{12}$ & 94.1 & 0.928 & 24 & $0.32 \sim 0.34$ & [45] \\
\hline $\mathrm{Li}_{6.4} \mathrm{La}_{3} \mathrm{Zr}_{1.4} \mathrm{Ta}_{0.6} \mathrm{O}_{12}+\mathrm{Li}_{4} \mathrm{SiO}_{4}$ & -- & 0.61 & 33 & 0.34 & [46] \\
\hline $\mathrm{Al}$-doped $\mathrm{Li}_{7} \mathrm{La}_{3} \mathrm{Zr}_{1.625} \mathrm{Ta}_{0.375} \mathrm{O}_{12}$ & -- & 0.409 & 25 & 0.30 & [15] \\
\hline $\mathrm{Li}_{6.6} \mathrm{La}_{2.5} \mathrm{Y}_{0.5} \mathrm{Zr}_{1.6} \mathrm{Ta}_{0.6} \mathrm{O}_{12}$ & -- & 0.436 & 27 & 0.34 & [47] \\
\hline $\mathrm{Li}_{6.5} \mathrm{La}_{3} \mathrm{Zr}_{1.75} \mathrm{Te}_{0.25} \mathrm{O}_{12}$ & -- & 1.02 & 30 & 0.37 & [48] \\
\hline Al-doped $\mathrm{Li}_{7-2 x} \mathrm{La}_{2} \mathrm{Zr}_{2-x} \mathrm{Te}_{x} \mathrm{O}_{12}$ & 82.4 & 0.40 & \multirow{2}{*}{27} & 0.33 & \multirow{2}{*}{ [16] } \\
\hline $\mathrm{Li}_{7-2 x} \mathrm{La}_{2} \mathrm{Zr}_{2-x} \mathrm{Te}_{x} \mathrm{O}_{12}$ & 80.2 & 0.369 & & 0.37 & \\
\hline $\mathrm{Li}_{6.5-3 y} \mathrm{Al}_{y} \mathrm{La}_{3} \mathrm{Zr}_{1.75} \mathrm{~W}_{0.25} \mathrm{O}_{12}$ & $93 \sim 95$ & 0.49 & 25 & 0.35 & [29] \\
\hline $\mathrm{Li}_{6.75} \mathrm{La}_{3} \mathrm{Zr}_{1.75} \mathrm{Nb}_{0.25} \mathrm{O}_{12}$ & -- & 0.80 & 25 & 0.31 & [49] \\
\hline Al-doped $\mathrm{Li}_{7} \mathrm{La}_{3} \mathrm{Zr}_{2} \mathrm{O}_{12}+\mathrm{Li}_{3} \mathrm{BO}_{3}$ & -- & 0.1 & 30 & 0.36 & [50] \\
\hline Al-doped $\mathrm{Li}_{7} \mathrm{La}_{3} \mathrm{Zr}_{2} \mathrm{O}_{12}$ & -- & 0.4 & 25 & 0.41 & [51] \\
\hline $\mathrm{Li}_{7} \mathrm{La}_{3} \mathrm{Zr}_{2-0.75 \mathrm{x}} \mathrm{Al}_{\mathrm{x}} \mathrm{O}_{12}$ & 82 & 0.34 & 25 & 0.33 & [52] \\
\hline Ge-doped $\mathrm{Li}_{7} \mathrm{La}_{3} \mathrm{Zr}_{2} \mathrm{O}_{12}$ & -- & 0.763 & 25 & -- & [53] \\
\hline $\mathrm{Li}_{7.06} \mathrm{La}_{3} \mathrm{Y}_{0.06} \mathrm{Zr}_{1.94} \mathrm{O}_{12}$ & -- & 0.81 & 25 & 0.26 & [54] \\
\hline Al-doped $\mathrm{Li}_{7} \mathrm{La}_{3} \mathrm{Zr}_{2} \mathrm{O}_{12}$ & -- & 0.2 & 25 & -- & [55] \\
\hline Al-doped $\mathrm{Li}_{7} \mathrm{La}_{3} \mathrm{Zr}_{2} \mathrm{O}_{12}$ & 99 & 0.37 & $\mathrm{RT}$ & -- & [56] \\
\hline Al-doped $\mathrm{Li}_{7} \mathrm{La}_{3} \mathrm{Zr}_{2} \mathrm{O}_{12}$ & -- & 0.244 & 25 & 0.34 & [11] \\
\hline
\end{tabular}


Table 3. DC conductivity $\left(\sigma_{D C}\right)$, jumping rate $\left(\omega_{c}\right)$, frequency exponent $(n)$, concentration $\left(n_{c}\right)$,

mobility $(\mu)$, and diffusion coefficient $(D)$ of charge carriers for $\mathrm{Li}_{7-3 x} \mathrm{Ga}_{x} \mathrm{La}_{3} \mathrm{Zr}_{2} \mathrm{O}_{12}$ samples

\begin{tabular}{|c|c|c|c|c|c|c|c|}
\hline Sample & $\begin{array}{l}\text { Temp. } \\
\left({ }^{\circ} \mathrm{C}\right)\end{array}$ & $\begin{array}{c}\sigma_{D C} \\
(\mathrm{mS} / \mathrm{cm}) \\
\end{array}$ & $\begin{array}{c}\omega_{c} \\
\left(10^{7} \mathrm{rad} / \mathrm{s}\right) \\
\end{array}$ & $n$ & $\begin{array}{c}n_{c} \\
\left(10^{21} \mathrm{~cm}^{-3}\right)\end{array}$ & $\begin{array}{c}\mu \\
\left(10^{-7} \mathrm{~cm}^{2} \mathrm{~V}^{-1} \mathrm{~s}^{-1}\right) \\
\end{array}$ & $\begin{array}{c}D \\
\left(10^{-8} \mathrm{~cm}^{2} \mathrm{~s}^{-1}\right) \\
\end{array}$ \\
\hline \multirow{3}{*}{$\mathrm{Li}_{6.40} \mathrm{Ga}_{0.20} \mathrm{La}_{3} \mathrm{Zr}_{2} \mathrm{O}_{12}$} & -10 & 0.187 & 5.65 & 0.59 & 1.18 & 9.96 & 2.26 \\
\hline & -30 & 0.075 & 2.57 & 0.90 & 0.96 & 4.90 & 1.02 \\
\hline & -60 & 0.011 & 0.35 & 0.89 & 0.89 & 0.76 & 0.14 \\
\hline \multirow{3}{*}{$\mathrm{Li}_{6.25} \mathrm{Ga}_{0.25} \mathrm{La}_{3} \mathrm{Zr}_{2} \mathrm{O}_{12}$} & -10 & 0.380 & 14.73 & 0.74 & 0.92 & 25.96 & 5.95 \\
\hline & -30 & 0.153 & 3.51 & 0.93 & 1.43 & 6.68 & 1.40 \\
\hline & -60 & 0.025 & 0.46 & 0.91 & 1.58 & 1.00 & 0.18 \\
\hline \multirow{3}{*}{$\mathrm{Li}_{6.10} \mathrm{Ga}_{0.30} \mathrm{La}_{3} \mathrm{Zr}_{2} \mathrm{O}_{12}$} & -10 & 0.293 & 5.18 & 0.91 & 2.01 & 9.12 & 2.08 \\
\hline & -30 & 0.116 & 2.17 & 0.94 & 1.75 & 4.14 & 0.86 \\
\hline & -60 & 0.020 & 0.26 & 0.97 & 2.18 & 0.58 & 0.10 \\
\hline \multirow{3}{*}{$\mathrm{Li}_{5.95} \mathrm{Ga}_{0.35} \mathrm{La}_{3} \mathrm{Zr}_{2} \mathrm{O}_{12}$} & -10 & 0.183 & 12.72 & 0.47 & 0.51 & 22.24 & 5.08 \\
\hline & -30 & 0.068 & 1.67 & 0.58 & 1.34 & 3.18 & 0.66 \\
\hline & -60 & 0.011 & 0.26 & 0.67 & 1.23 & 0.58 & 0.10 \\
\hline \multirow{3}{*}{$\mathrm{Li}_{5.80} \mathrm{Ga}_{0.40} \mathrm{La}_{3} \mathrm{Zr}_{2} \mathrm{O}_{12}$} & -10 & 0.135 & 3.09 & 0.90 & 1.55 & 5.44 & 1.24 \\
\hline & -30 & 0.052 & 1.04 & 0.92 & 1.65 & 1.98 & 0.42 \\
\hline & -60 & 0.009 & 0.15 & 0.92 & 1.66 & 0.32 & 0.06 \\
\hline Ref. ${ }^{28}$ & -63 & 8.44E-4 & 0.0634 & 0.51 & 3.12 & 0.0169 & 0.003 \\
\hline Ref. ${ }^{29}$ & -30 & $8.47 \mathrm{E}-3$ & 0.88 & 0.966 & 1.98 & 1.677 & 0.35 \\
\hline
\end{tabular}


Table 4. Structural parameters of $\mathrm{Li}_{6.40} \mathrm{Ga}_{0.20} \mathrm{La}_{3} \mathrm{Zr}_{2} \mathrm{O}_{12}$ and $\mathrm{Li}_{6.10} \mathrm{Ga}_{0.30} \mathrm{La}_{3} \mathrm{Zr}_{2} \mathrm{O}_{12}$ samples obtained using NPD data (space group Ia $\overline{3} d$ )

\begin{tabular}{|c|c|c|c|c|c|c|c|c|c|c|}
\hline & Stoichiometry & $\begin{array}{c}\text { Lattice } \\
\text { parameter } \\
\quad(\mathrm{nm})\end{array}$ & $\begin{array}{l}\mathrm{R}_{\mathrm{wp}} \\
(\%)\end{array}$ & GOF & Site & Occupancy & $x$ & $y$ & $z$ & $\mathrm{U}_{\mathrm{iso}}\left(\AA^{2}\right)$ \\
\hline \multirow{3}{*}{$\mathrm{Li}_{6.40} \mathrm{Ga}_{0.20} \mathrm{La}_{3} \mathrm{Zr}_{2} \mathrm{O}_{12}$} & \multirow{3}{*}{$\mathrm{Li}^{24 d}{ }_{1.65(9)} \mathrm{Ga}^{24 d}{ }_{0.2} \mathrm{Li}^{96 h}{ }_{4.74(11)} \mathrm{La}_{3} \mathrm{Zr}_{2} \mathrm{O}_{12}$} & \multirow{3}{*}{$1.29733(6)$} & \multirow{3}{*}{3.58} & \multirow{3}{*}{1.52} & $\operatorname{Li1}(24 d)$ & $0.55(3)$ & $3 / 8$ & 0 & $1 / 4$ & $0.066(15)$ \\
\hline & & & & & $\mathrm{Ga}(24 d)$ & 0.067 & $3 / 8$ & 0 & $1 / 4$ & $0.066(15)$ \\
\hline & & & & & $\mathrm{La}(24 c)$ & 1 & $1 / 8$ & 0 & $1 / 4$ & $0.070(4)$ \\
\hline \multirow{5}{*}{\multicolumn{2}{|c|}{$\mathrm{Li}_{6.10} \mathrm{Ga}_{0.30} \mathrm{La}_{3} \mathrm{Zr}_{2} \mathrm{O}_{12} \quad \mathrm{Li}^{24 d}{ }_{1.03(6)} \mathrm{Ga}^{24 d}{ }_{0.3} \mathrm{Li}^{96 h}{ }_{3.96(12)} \mathrm{La}_{3} \mathrm{Zr}_{2} \mathrm{O}_{12}$}} & \multirow{5}{*}{$1.29746(9)$} & \multirow{5}{*}{3.36} & \multirow{5}{*}{1.46} & $\operatorname{Li1}(24 d)$ & $0.34(2)$ & $3 / 8$ & 0 & $1 / 4$ & $0.009(1)$ \\
\hline & & & & & $\operatorname{Li} 2(96 h)$ & $0.33(1)$ & $0.100(1)$ & $0.191(1)$ & $0.421(1)$ & $0.009(1)$ \\
\hline & & & & & $\mathrm{Ga}(24 d)$ & 0.1 & $3 / 8$ & 0 & $1 / 4$ & $0.009(1)$ \\
\hline & & & & & $\mathrm{La}(24 c)$ & 1 & $1 / 8$ & 0 & $1 / 4$ & $0.009(1)$ \\
\hline & & & & & $\operatorname{Zr}(16 a)$ & 1 & 0 & 0 & 0 & $0.009(1)$ \\
\hline
\end{tabular}


Figures
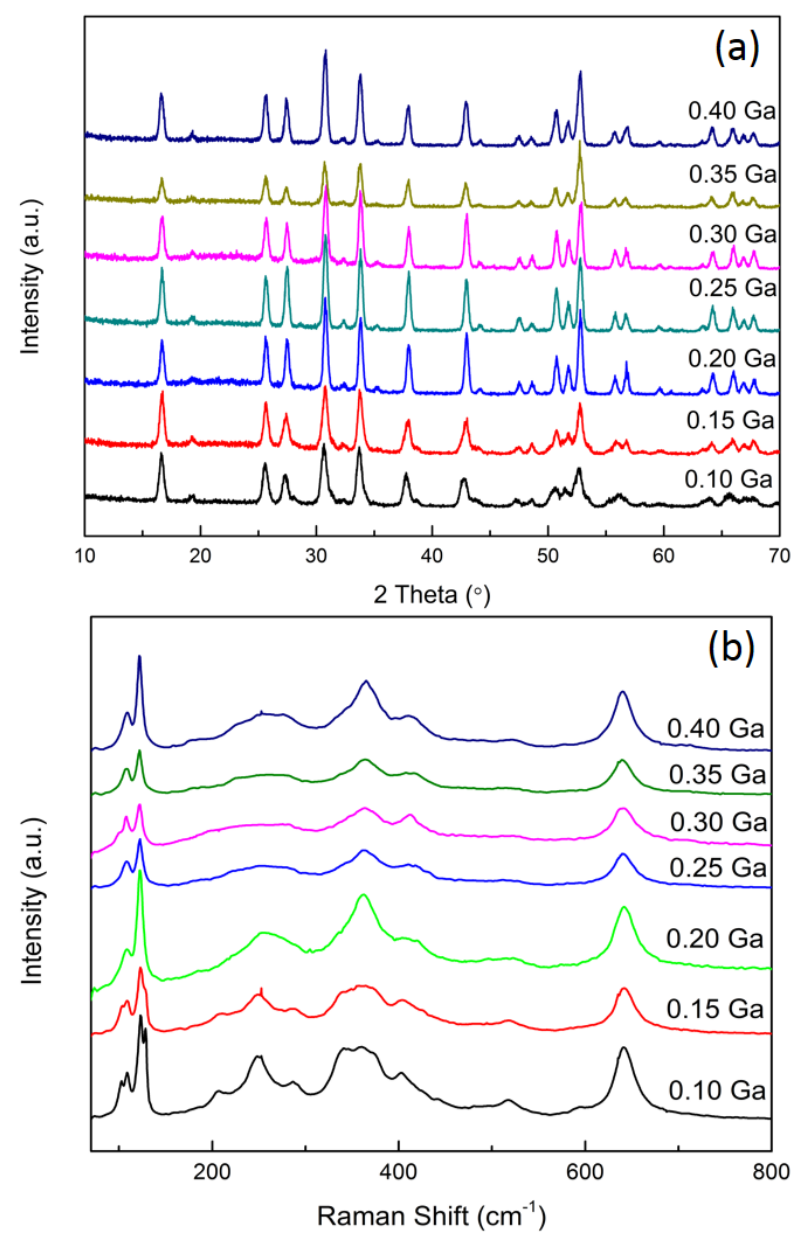

Fig. 1 (a) XRD patterns and (b) Raman spectra of $\mathrm{Li}_{7-3 x} \mathrm{Ga}_{x} \mathrm{La}_{3} \mathrm{Zr}_{2} \mathrm{O}_{12}$ samples. 

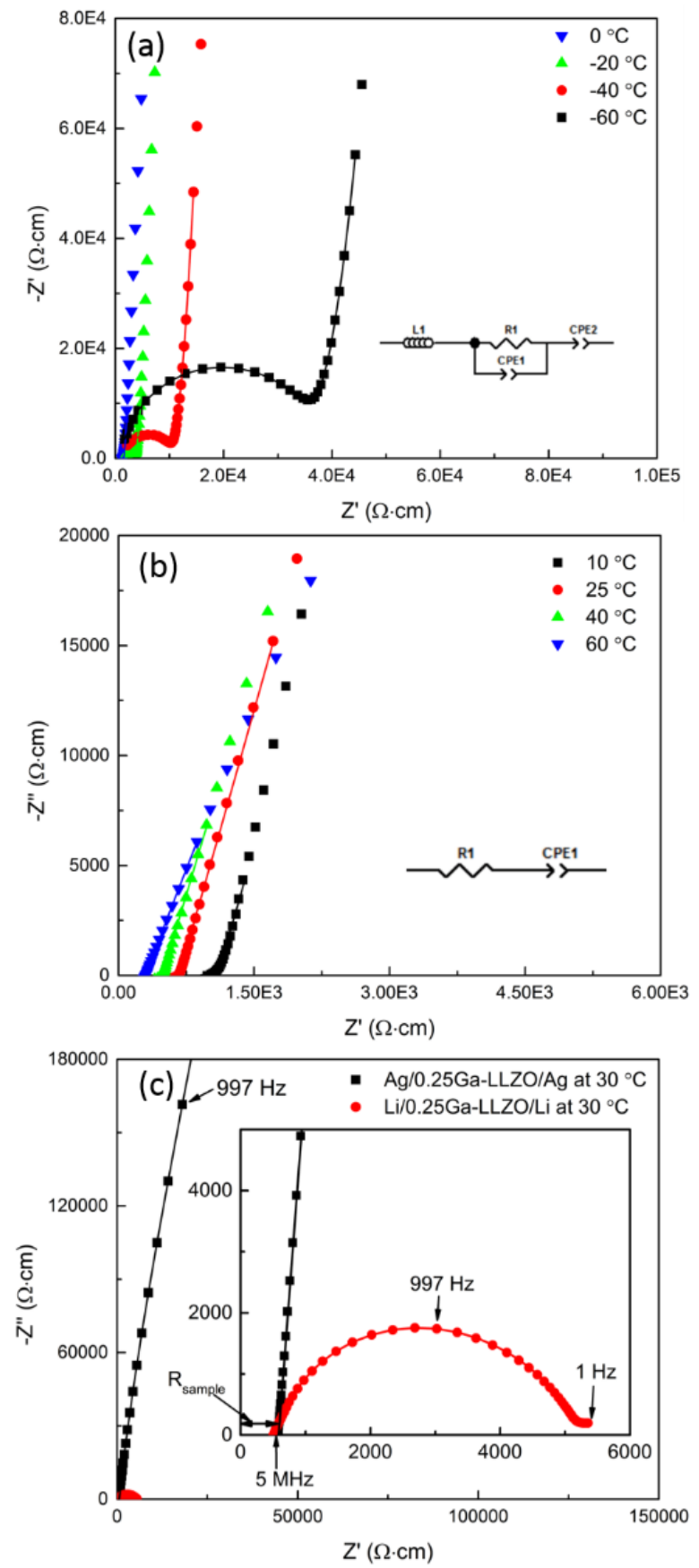

Fig. 2 AC impedance spectra and fitting results of $\mathrm{Li}_{6.25} \mathrm{Ga}_{0.25} \mathrm{La}_{3} \mathrm{Zr}_{2} \mathrm{O}_{12}$ (a, b) at different temperatures, and (c) with $\mathrm{Ag}$ and $\mathrm{Li}$ electrodes at $30{ }^{\circ} \mathrm{C}$. The insets in (a) and (b) are the equivalent circuits used. The inset in (c) represents the high frequency regions of the corresponding impedance spectra. 


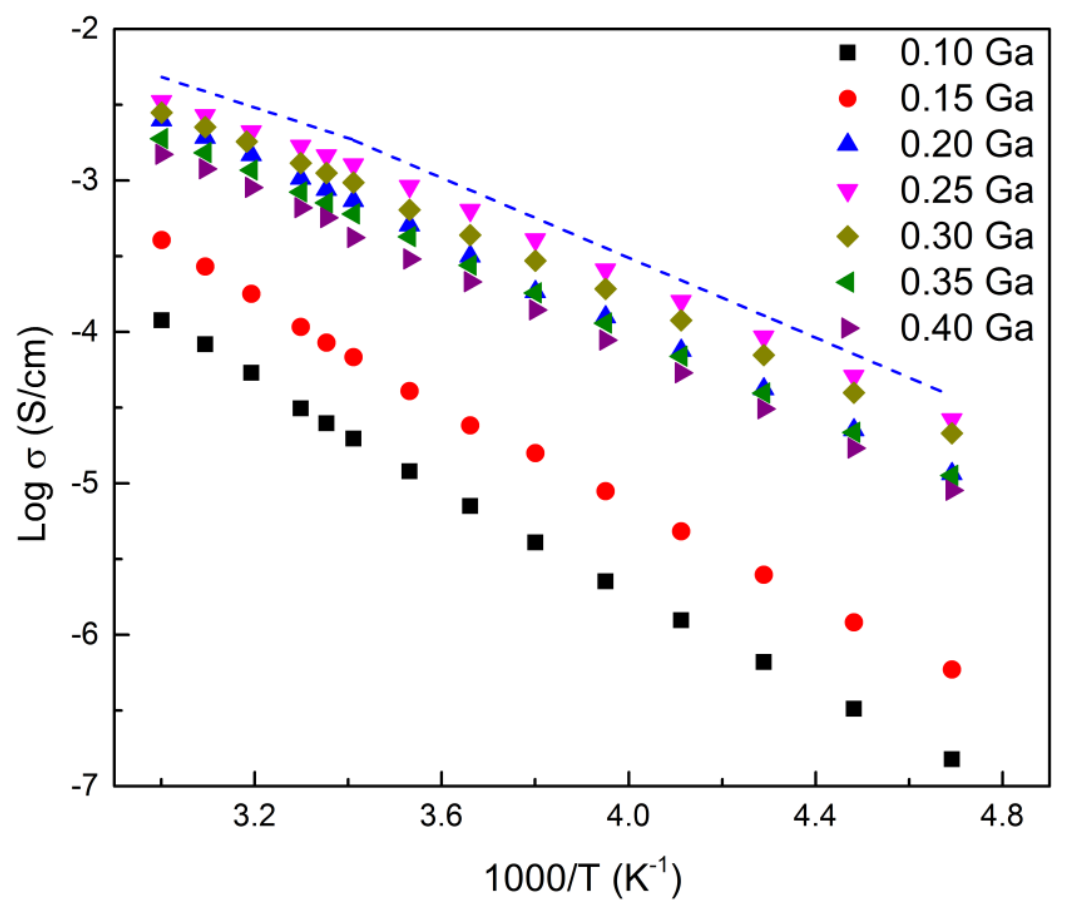

Fig. 3 Temperature dependence of the conductivity of $\mathrm{Li}_{7-3 x} \mathrm{Ga}_{x} \mathrm{La}_{3} \mathrm{Zr}_{2} \mathrm{O}_{12}$ samples. The dashed line shows the slops at high and low temperatures. 


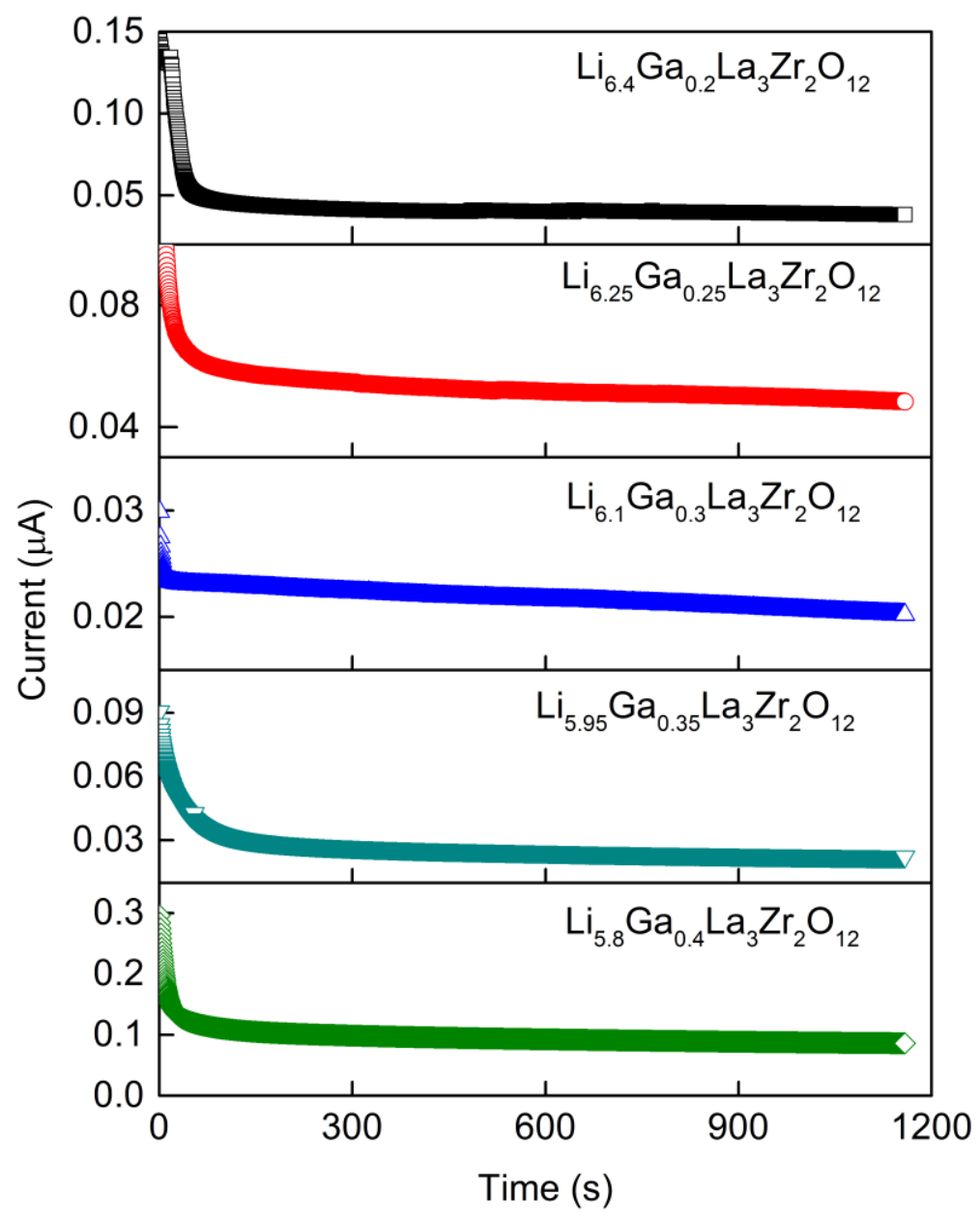

Fig. 4 DC polarization plots of $\mathrm{Li}_{7-3 x} \mathrm{Ga}_{x} \mathrm{La}_{3} \mathrm{Zr}_{2} \mathrm{O}_{12}$ samples. 

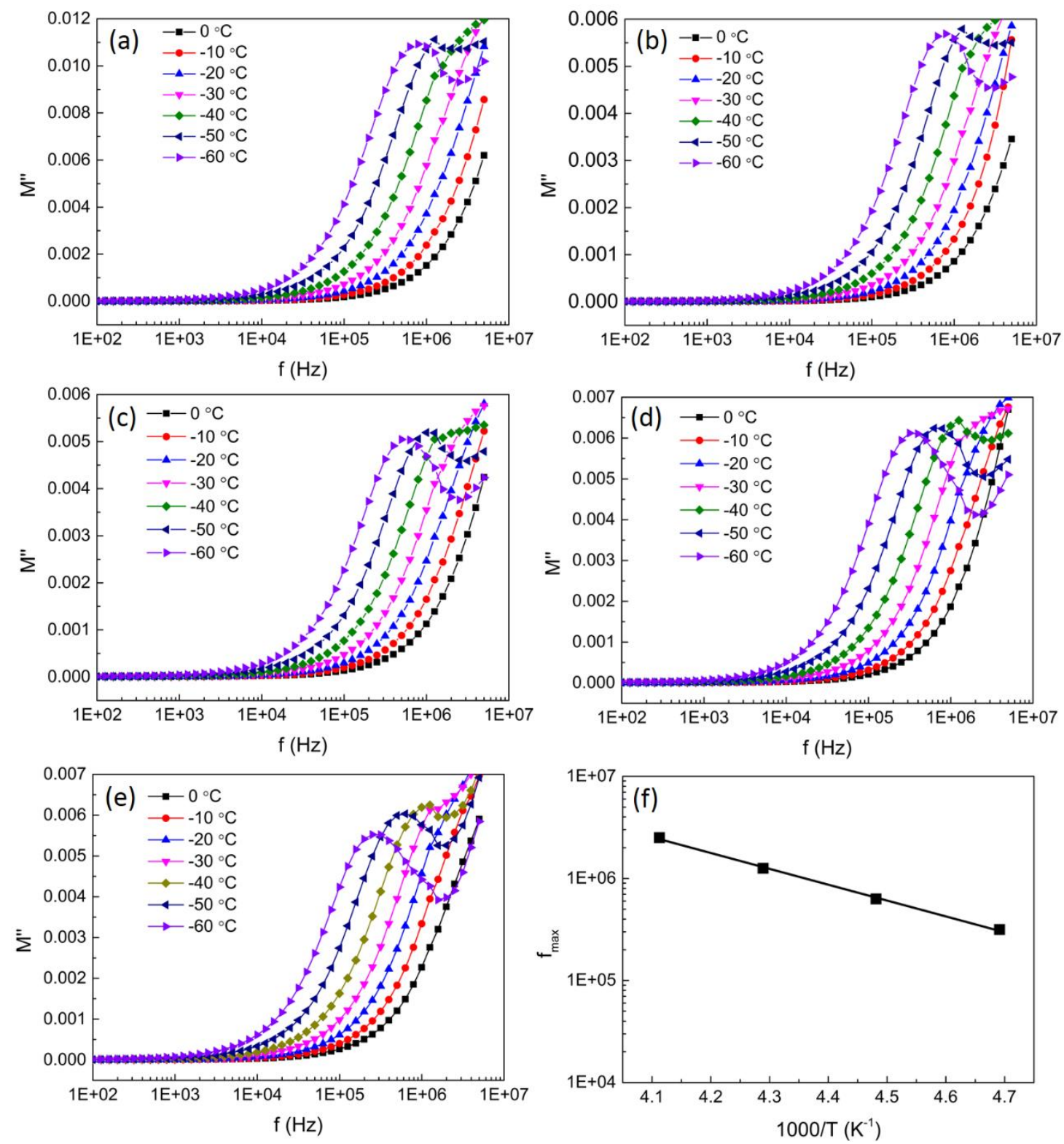

Fig. 5 Frequency dependence of $M^{\prime \prime}$ for $\mathrm{Li}_{7-3 x} \mathrm{Ga}_{x} \mathrm{La}_{3} \mathrm{Zr}_{2} \mathrm{O}_{12}$ samples with different $x$ values: (a)

0.20 , (b) 0.25 , (c) 0.30 , (d) 0.35 and (e) 0.40 , and (f) temperature dependence of $f_{\max }$ for $\mathrm{Li}_{5.80} \mathrm{Ga}_{0.40} \mathrm{La}_{3} \mathrm{Zr}_{2} \mathrm{O}_{12}$ sample. 

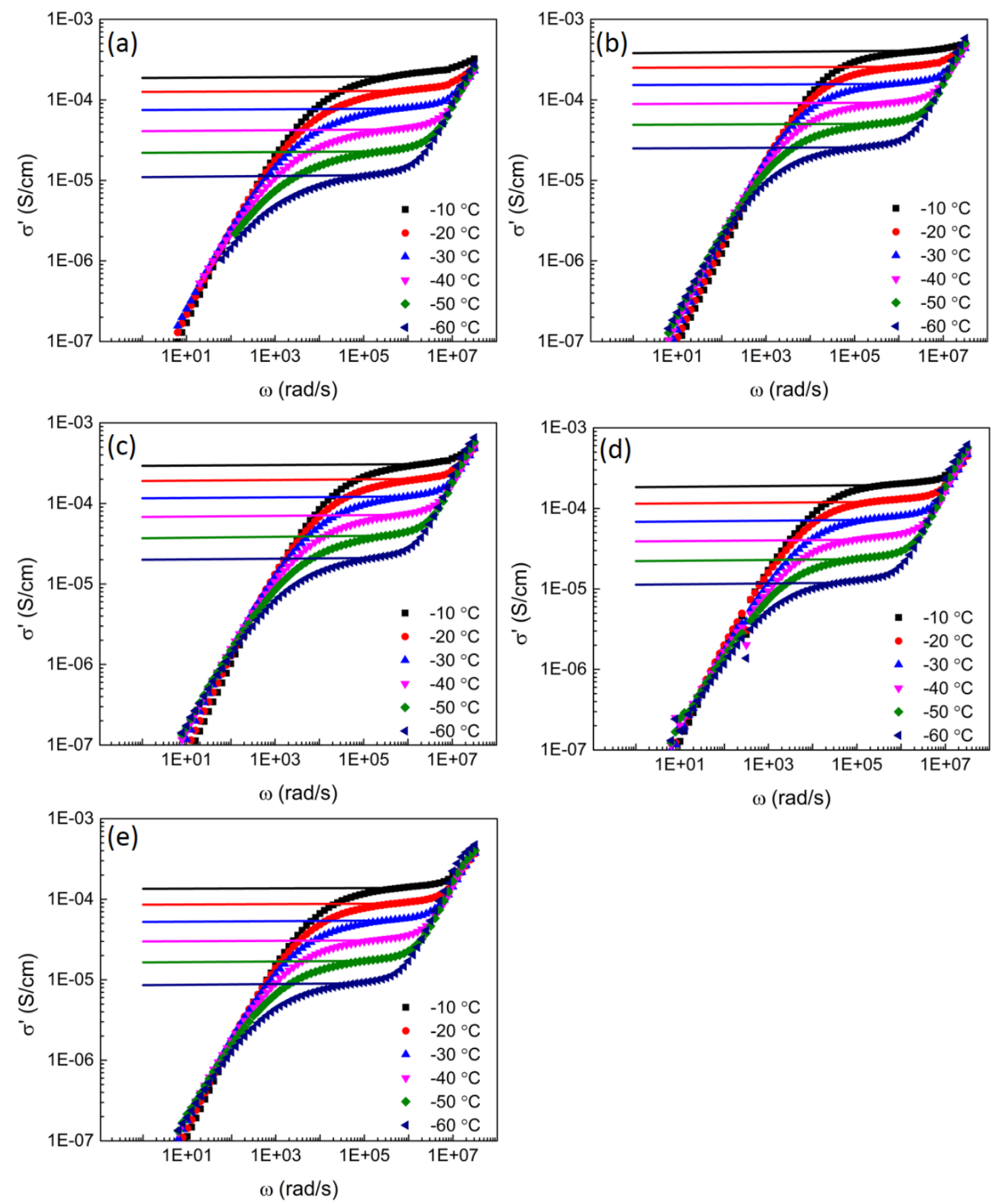

Fig. 6 Frequency dependent $\sigma(\omega)$ of $\mathrm{Li}_{7-3 x} \mathrm{Ga}_{x} \mathrm{La}_{3} \mathrm{Zr}_{2} \mathrm{O}_{12}$ samples with different $x$ values: (a) 0.20 ,

(b) 0.25 , (c) 0.30 , (d) 0.35 and (e) 0.40 . 

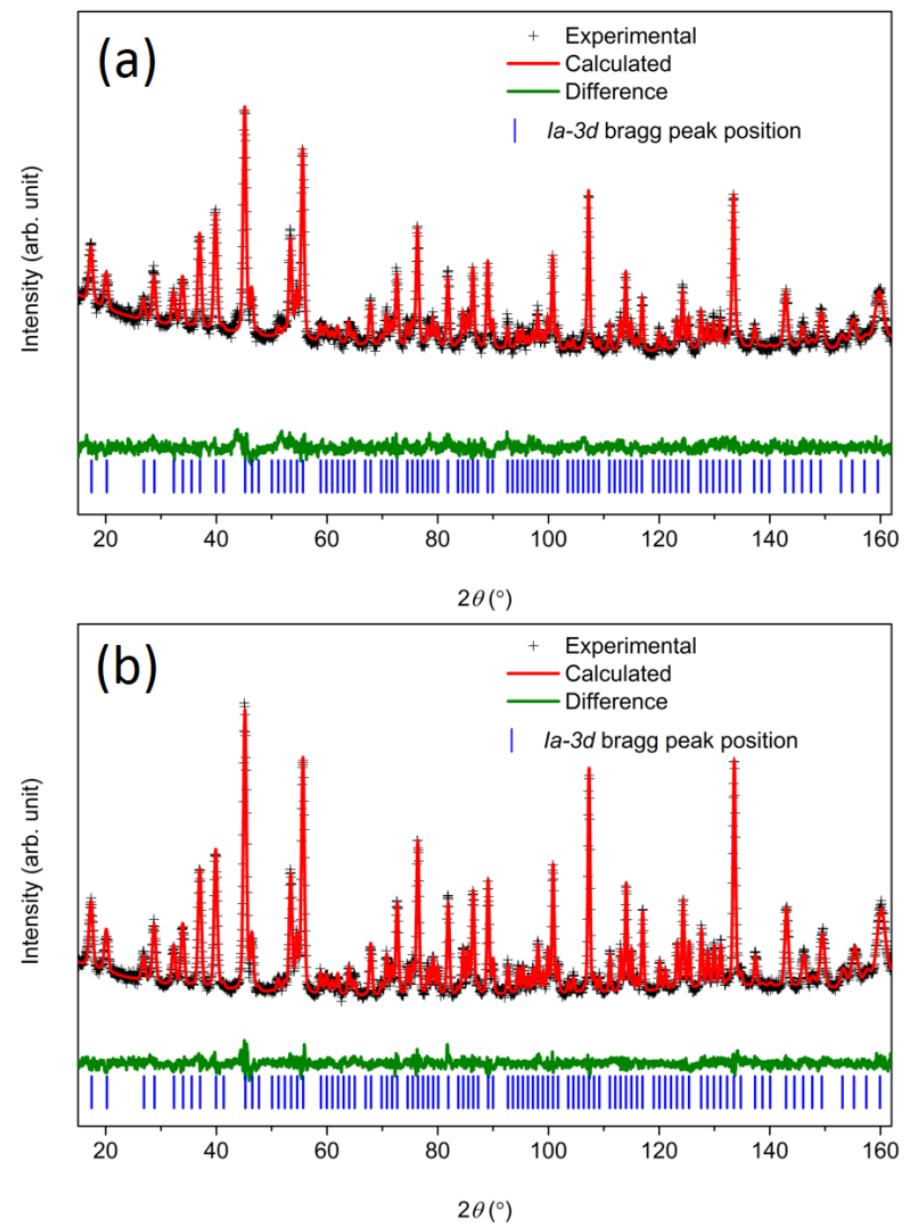

Fig. 7 Rietveld refinement plots using room temperature NPD data for (a) $\mathrm{Li}_{6.40} \mathrm{Ga}_{0.20} \mathrm{La}_{3} \mathrm{Zr}_{2} \mathrm{O}_{12}$ and (b) $\mathrm{Li}_{6.10} \mathrm{Ga}_{0.30} \mathrm{La}_{3} \mathrm{Zr}_{2} \mathrm{O}_{12}$ samples. 

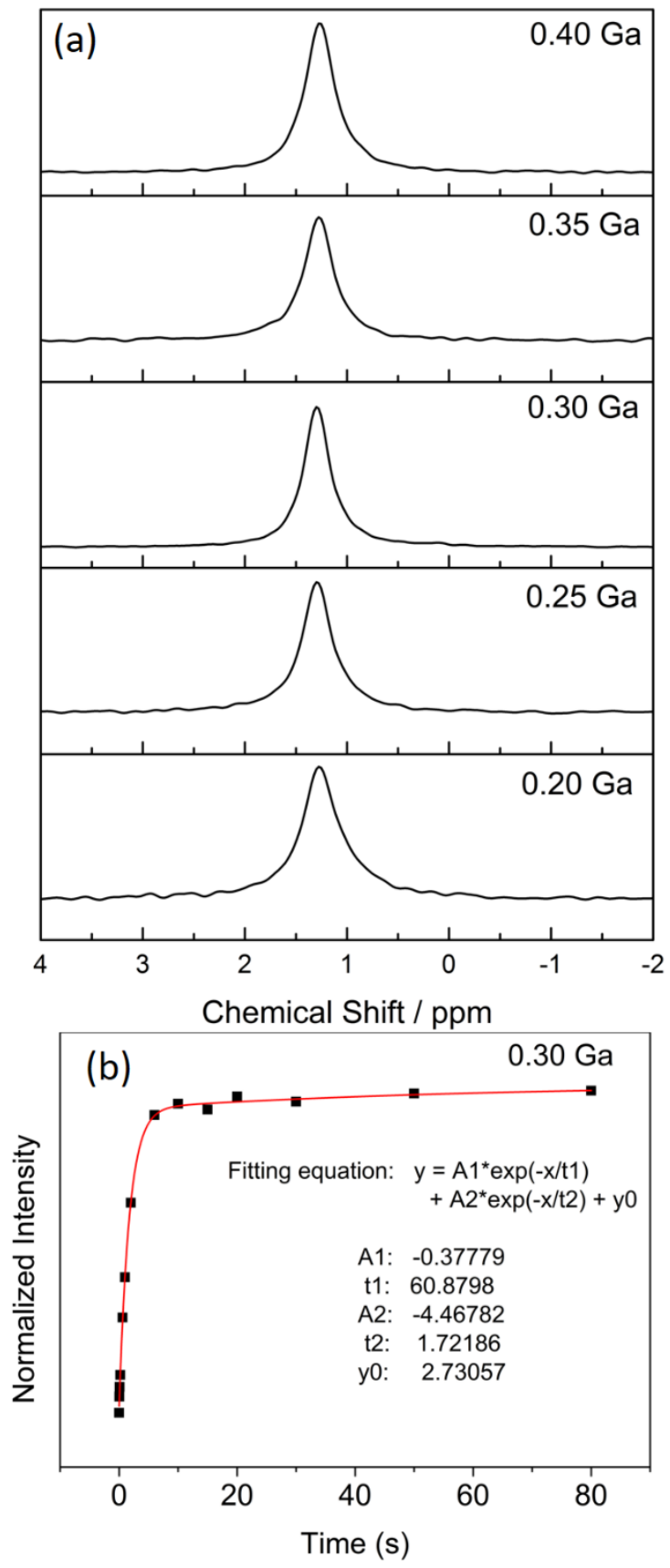

Fig. 8 (a) ${ }^{6} \mathrm{Li}$ MAS NMR spectra of $\mathrm{Li}_{7-3 x} \mathrm{Ga}_{x} \mathrm{La}_{3} \mathrm{Zr}_{2} \mathrm{O}_{12}$ samples with $x$ values shown inset, and (b) spin-lattice relaxation curve and fitting result of $\mathrm{Li}_{6.10} \mathrm{Ga}_{0.30} \mathrm{La}_{3} \mathrm{Zr}_{2} \mathrm{O}_{12}$. In the fitting equation, A1 and t1 represent the smaller component with a longer spin-lattice relaxation time, while A2 and $\mathrm{t} 2$ represent the larger component with a shorter spin-lattice relaxation time. 


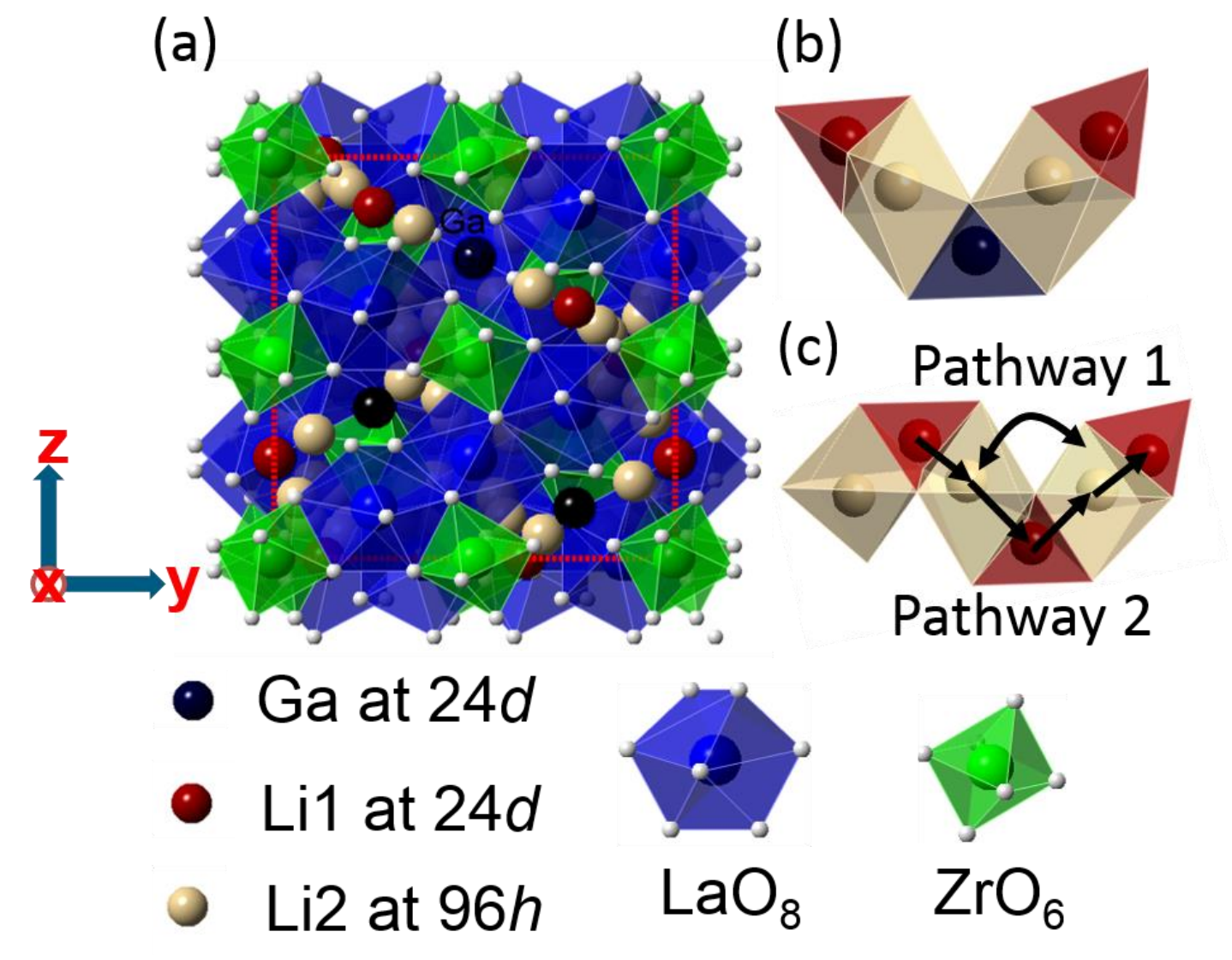

(b)

Fig. 9. (a) Crystal structure of $\mathrm{Li}_{7-3 x} \mathrm{Ga}_{x} \mathrm{La}_{3} \mathrm{Zr}_{2} \mathrm{O}_{12}$, (b) $\mathrm{Li}^{+}$and $\mathrm{Ga}^{3+}$ environment, and (c) lithium-ion diffusion pathways in $\mathrm{Li}_{7-3 x} \mathrm{Ga}_{x} \mathrm{La}_{3} \mathrm{Zr}_{2} \mathrm{O}_{12}$. 


\section{Table of Contents}

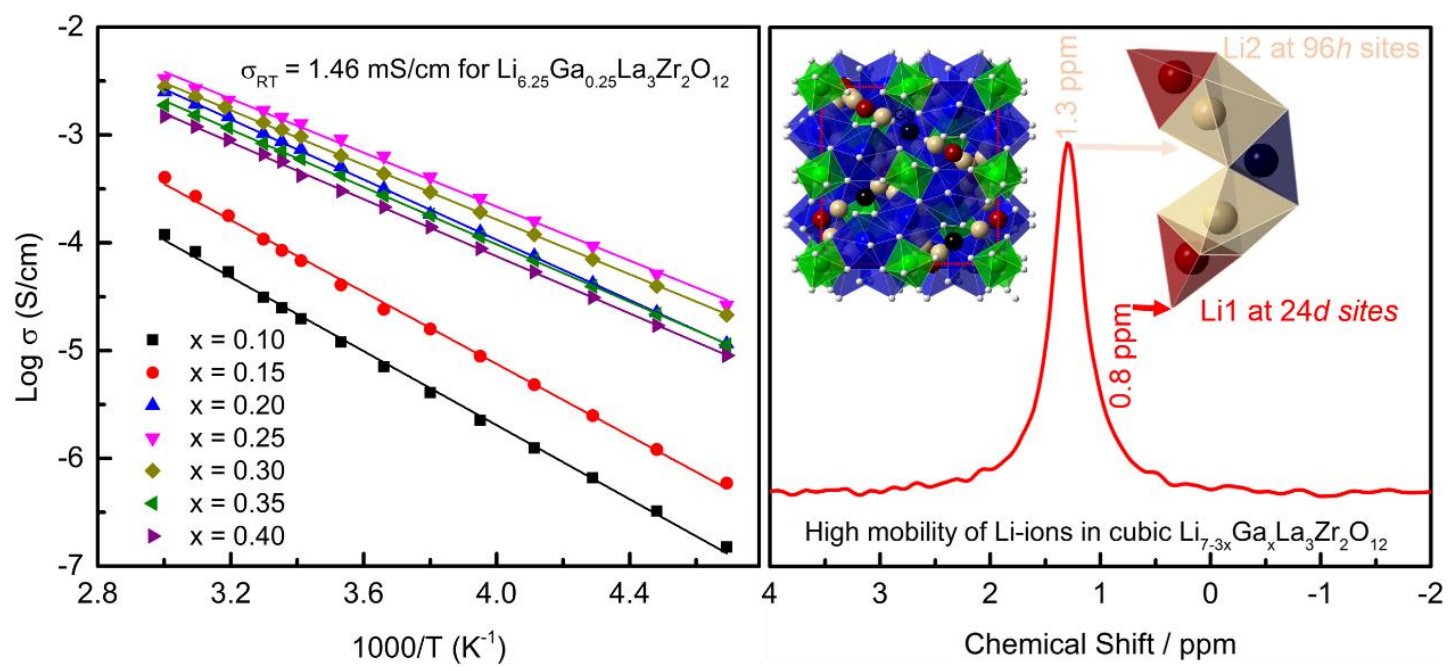

